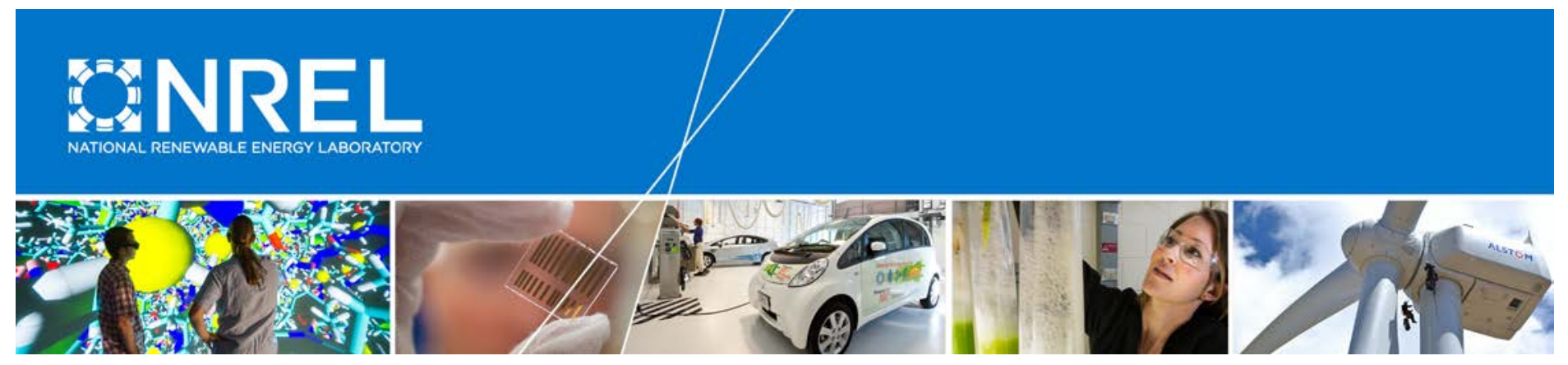

\title{
A Primer on Motor Fuel Excise Taxes and the Role of Alternative Fuels and Energy Efficient Vehicles
}

Alex Schroeder

National Renewable Energy Laboratory

NREL is a national laboratory of the U.S. Department of Energy Office of Energy Efficiency \& Renewable Energy Operated by the Alliance for Sustainable Energy, LLC

This report is available at no cost from the National Renewable Energy Laboratory (NREL) at www.nrel.gov/publications.

Technical Report

NREL/TP-5400-60975

August 2015

Contract No. DE-AC36-08G028308 


\section{A Primer on Motor Fuel Excise Taxes and the Role of Alternative Fuels and Energy Efficient Vehicles}

Alex Schroeder

National Renewable Energy Laboratory

Prepared under Task No(s). VTP2.0310
NREL is a national laboratory of the U.S. Department of Energy Office of Energy Efficiency \& Renewable Energy Operated by the Alliance for Sustainable Energy, LLC

This report is available at no cost from the National Renewable Energy Laboratory (NREL) at www.nrel.gov/publications.

\section{Technical Report}

NREL/TP-5400-60975

August 2015

Contract No. DE-AC36-08G028308
National Renewable Energy Laboratory 15013 Denver West Parkway

Golden, CO 80401

303-275-3000 • www.nrel.gov 


\section{NOTICE}

This report was prepared as an account of work sponsored by an agency of the United States government. Neither the United States government nor any agency thereof, nor any of their employees, makes any warranty, express or implied, or assumes any legal liability or responsibility for the accuracy, completeness, or usefulness of any information, apparatus, product, or process disclosed, or represents that its use would not infringe privately owned rights. Reference herein to any specific commercial product, process, or service by trade name, trademark, manufacturer, or otherwise does not necessarily constitute or imply its endorsement, recommendation, or favoring by the United States government or any agency thereof. The views and opinions of authors expressed herein do not necessarily state or reflect those of the United States government or any agency thereof.

This report is available at no cost from the National Renewable Energy Laboratory (NREL) at www.nrel.gov/publications.

Available electronically at SciTech Connect http:/www.osti.gov/scitech

Available for a processing fee to U.S. Department of Energy and its contractors, in paper, from:

U.S. Department of Energy

Office of Scientific and Technical Information

P.O. Box 62

Oak Ridge, TN 37831-0062

OSTI http://www.osti.gov

Phone: 865.576.8401

Fax: 865.576.5728

Email: reports@osti.gov

Available for sale to the public, in paper, from:

U.S. Department of Commerce

National Technical Information Service

5301 Shawnee Road

Alexandria, VA 22312

NTIS http://www.ntis.gov

Phone: 800.553 .6847 or 703.605 .6000

Fax: 703.605.6900

Email: orders@ntis.gov 


\section{Acknowledgments}

The U.S. Department of Energy's (DOE) Office of Energy Efficiency and Renewable Energy funded this work. DOE's Clean Cities program director Dennis Smith has been particularly encouraging and enabling of this pursuit. The author would like to thank John Farrell, Margo Melendez, Wendy Dafoe, George Mitchell, Caley Johnson, and Kristi Moriarty of the National Renewable Energy Laboratory (NREL) for their input and guidance on the content and analysis contained in this report. The author would also like to thank the numerous external reviewers who provided valuable comments and helpful suggestions. The wide variety of reviews greatly added to the robustness and accuracy of the report, but any errors herein are solely the author's responsibility. The author also offers his thanks to Steve Lommele, Kathy Cisar, and Julie Sutor in the NREL Communications Office for providing editorial support. 


\section{List of Acronyms}

$\begin{array}{ll}\text { AFDC } & \text { Alternative Fuels Data Center } \\ \text { AFV } & \text { alternative fuel vehicle } \\ \text { BTU } & \text { British thermal unit } \\ \text { CAFE } & \text { Corporate Average Fuel Economy } \\ \text { CARB } & \text { California Air Resources Board } \\ \text { CBO } & \text { U.S. Congressional Budget Office } \\ \text { CNG } & \text { compressed natural gas } \\ \text { DMV } & \text { department of motor vehicles } \\ \text { DOE } & \text { U.S. Department of Energy } \\ \text { ECB } & \text { energy-content based } \\ \text { EPA } & \text { U.S. Environmental Protection Agency } \\ \text { EV } & \text { all-electric vehicle } \\ \text { GGE } & \text { gasoline gallon equivalent } \\ \text { HEV } & \text { hybrid electric vehicle } \\ \text { HTF } & \text { Highway Trust Fund } \\ \text { ICE } & \text { internal combustion engine } \\ \text { IFTA } & \text { International Fuel Tax Agreement } \\ \text { IRS } & \text { U.S. Internal Revenue Service } \\ \text { kWh } & \text { kilowatt-hour } \\ \text { LNG } & \text { liquefied natural gas } \\ \text { LPG } & \text { liquefied petroleum gas } \\ \text { MPGe } & \text { miles per gallon equivalent } \\ \text { NREL } & \text { National Renewable Energy Laboratory } \\ \text { PEV } & \text { plug-in electric vehicle } \\ \text { PHEV } & \text { plug-in hybrid electric vehicle } \\ \text { RIN } & \text { renewable identification number } \\ \text { scf } & \text { standard cubic feet } \\ \text { VIN } & \text { vehicle identification number } \\ \text { VMT } & \text { vehicle miles traveled } \\ \text { ZEV } & \text { zero emission vehicle } \\ & \end{array}$




\section{Executive Summary}

Motor fuel taxes were established to finance our nation's transportation infrastructure, yet evolving economic, political, and technological influences are constraining this ability. At the federal level, the Highway Trust Fund (HTF), which is primarily funded by motor fuel taxes, has become increasingly dependent on general fund contributions and short-term reauthorizations to prevent insolvency. As a result, there are discussions at both the federal and state levels in which stakeholders are examining the future of motor fuel excise taxes as well as the role of electric and alternative fuel vehicles in that future. On July 1, 2015, six states increased their motor fuel tax rates.

The current state of transportation infrastructure funding has placed the policies of vehicle efficiency and petroleum use reduction at direct odds with those promoting robust transportation infrastructure. The increase in federal fuel efficiency standards for vehicle model years 2017 through 2025 is projected to provide a benefit to the U.S. economy of between $\$ 372$ and $\$ 507$ billion by 2025 (NHTSA 2012), but fuel tax revenues are projected to decrease by $\$ 57$ billion by 2022 (Dinan and Austin 2012). Additionally, the current method of calculating fuel taxes is based on volumetric measures or rough equivalencies, which does not always account for the energy content of the fuel, and the related distance traveled, as a direct indicator of a vehicle's impact on infrastructure. This penalizes a number of alternative, non-petroleum fuels. Furthermore, the introduction of plug-in electric vehicles into the consumer market (along with the option to charge at home, thereby largely avoiding fuel taxes) is directly cutting into transportation revenues. Accordingly, emerging technology raises important questions about collection mechanisms for motor fuel excise taxes. Decisions are being made or considered that may ultimately favor energy, transportation, or environmental outcomes and it will be important for decision makers to understand inherent trade-offs.

A number of states are looking at or have already implemented legislation that bases fuel taxation on the energy content of a fuel and/or have established fees to recover lost fuel revenues from alternative fuel and electric vehicles. These mechanisms, while limited in their ability to solve broader funding questions, can help to contribute to a greater tax parity among motor fuels and vehicle technologies. However, they can only do so if implemented in a way that balances a number of trade-offs. If implemented incorrectly, these mechanisms could have the unintended consequence of favoring certain fuels, vehicle technologies, and types of uses over others.

Beyond traditional motor fuel taxes, states and provinces are implementing or piloting other innovative funding mechanisms. For example, Virginia replaced their fuel excise tax with an indexed sales tax, allowing for adjustments to account for inflation. In July 2015, Oregon began piloting a tax on miles traveled as an alternative metric for taxing infrastructure use. British Columbia has implemented a carbon tax on motor fuels under its greenhouse gas regime. The experiences of these states and provinces, among others, are increasing the number of tools and knowledge available to policymakers who hope to align their energy and environmental priorities with adequate highway funding. 


\section{Table of Contents}

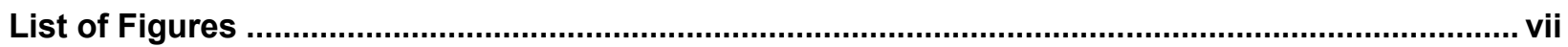

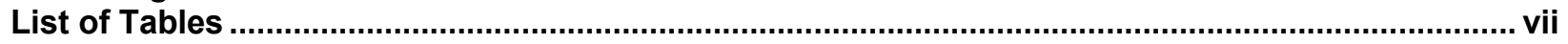

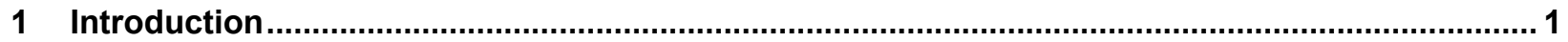

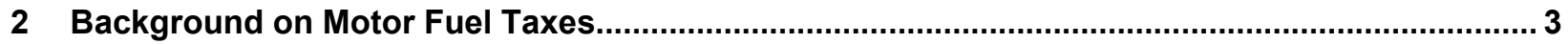

2.1 An Abridged History of Motor Fuel Taxes and Highway Funding Mechanisms .......................... 3

2.1.1 The Advent of State Motor Fuel Excise Taxes .............................................................. 3

2.1.2 State Registration Fees, Sales Taxes, and Other Sources of Transportation Revenue......... 3

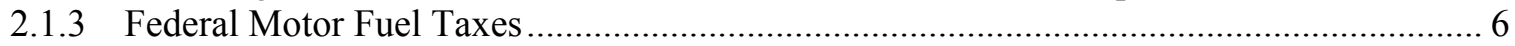

2.2 The Current State of the HTF: Rising Costs and Decreasing Revenues........................................ 7

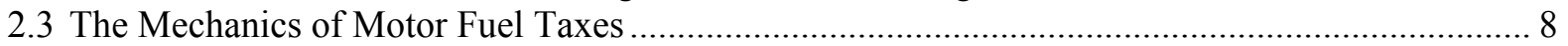

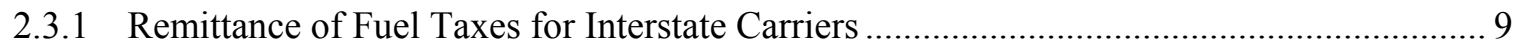

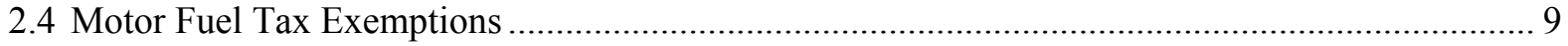

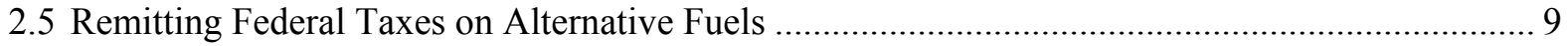

3 The Growing Role and Complications of Alternative Fuels and Advanced Vehicle

Technologies.

3.1 Growth in Alternative Fuel Use and Vehicle Availability ....................................................... 11

3.2 Challenges with Alternative Fuels and Advanced Technologies Under the Current System of

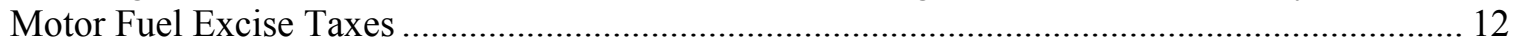

3.2.1 Increased Vehicle Efficiency and Reduced Vehicle Miles Traveled ................................. 13

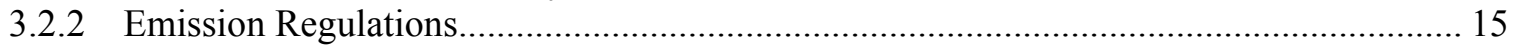

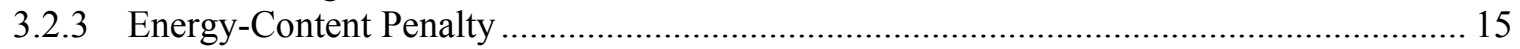

3.2.4 Weights and Measures for Non-Liquid Fuels ............................................................ 17

3.2.5 Electrification of Transportation and the Emergence of Home Fueling ........................... 17

4 Alternative Approaches to Volumetric Motor Fuel Excise Taxes................................................ 19

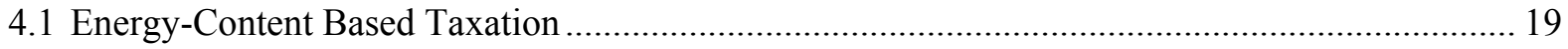

4.1.1 Considerations for Implementation of Energy-Content Based Taxation ........................... 21

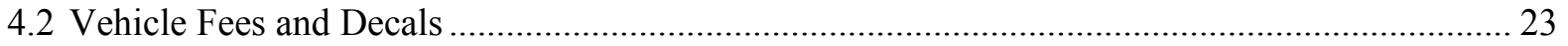

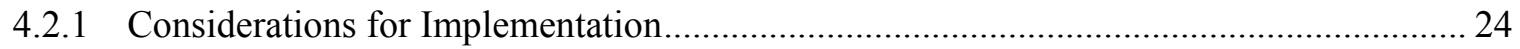

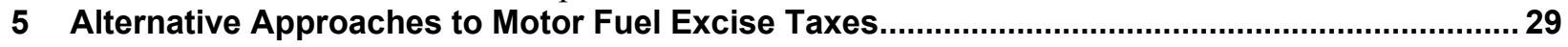

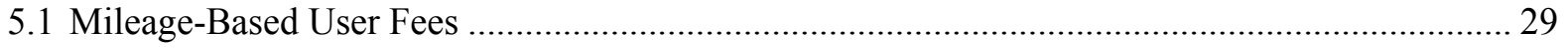

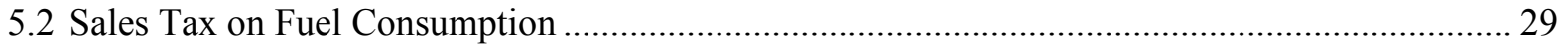

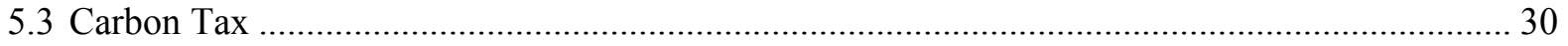

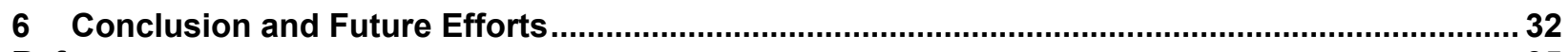

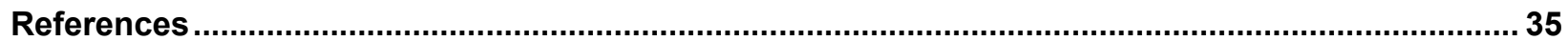




\section{List of Figures}

Figure 1. National highway funding contribution by source (2012)................................................... 3

Figure 2. Distribution of aggregate sources of state highway funding by type (2012) ..................... 4

Figure 3. Cumulative state and federal gasoline taxes in cents (July 2015)................................... 5

Figure 4. Cumulative state and federal diesel taxes in cents (July 2015) ...................................... 5

Figure 5. Federal Gasoline excise tax rates (1932-2015)......................................................... 6

Figure 6. Projections of the Highway Trust Fund balance (2012-2025) ........................................... 7

Figure 7. Cumulative gasoline and diesel consumption in gasoline gallon equivalents (1984-2014)8

Figure 8. Gasoline and diesel production supply chain.

Figure 9. Approximate number of gasoline, diesel, hybrid, electric, and alternative fuel light-duty vehicles (model years 1999-2015)

Figure 10. Alternative fuel, electric, and hybrid vehicle light-duty vehicle models by year ............ 12

Figure 11. Light-duty Corporate Average Fuel Economy (CAFE) standards by year........................ 13

Figure 12. Twelve-month rolling average of vehicle miles traveled in the U.S................................. 14

Figure 13. Cumulative plug-in electric vehicle sales.................................................................... 18

Figure 14. States with an annual fee of decal for CNG, LNG, and/or LPG ....................................... 23

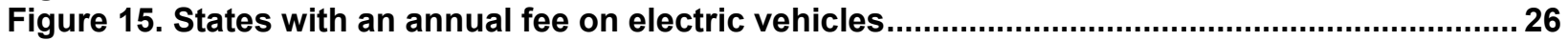

\section{List of Tables}

Table 1. Federal Motor Fuel Excise Tax Rates

Table 2. Energy Content, Gasoline Gallon Equivalence, and Federal Excise Tax Rates for Motor Fuels

Table 3. Energy-Content Based (ECB) Motor Fuel Excise Tax Rates Relative to the Energy Content

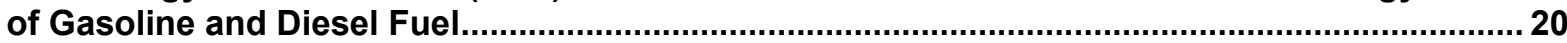

Table 4. Electricity Energy Equivalence to Gasoline and Diesel ................................................... 22

Table 5. Relative Per-Gallon Cost for Various Vehicle Classes with $\$ 100$ Annual Decal/Registration Fee.

Table 6. Estimate of Annual Federal Fuel Taxes Paid by an Average Conventional Vehicle, Nissan Leaf EV, and Chevrolet Volt PHEV if Electricity Were Taxed as a Motor Fuel ....

Table 7. Approximate Fuel Tax for a Nissan Leaf and Chevrolet Volt in the Context of Their Battery Capacities. 


\section{Introduction}

Across the nation, motor fuel taxes are responsible for generating a large majority of funds used to build and maintain our surface transportation infrastructure. Revenues generated from these taxes have increasingly lagged behind expenses and have recently relied on supplemental funding to meet demands. Tax rates are largely set through federal and state legislation while expenses are driven by (more dynamic) market forces such as infrastructure costs, inflation, and demographic shifts. Recent market trends, including increased vehicle efficiency and a decline in per capita vehicle miles traveled (VMT), are reducing fuel use and further constraining fuel tax revenues.

At the federal level, motor fuel taxes are responsible for generating $85 \%$ of the funds used for managing our transportation infrastructure. Yet figures from the U.S. Congressional Budget Office (CBO) showed a shortfall of $\$ 5$ billon between revenues and expenses for 2012, which has the effect of requiring revenue from other sources. The CBO projected that by 2015 the Highway Trust Fund (HTF) will be insolvent (Cawley 2013), which the U.S DOT has confirmed will happen pending further action. This comes at a time when U.S. infrastructure is deteriorating at a rate that outpaces improvements. In 2013, the American Society of Civil Engineers graded U.S. transportation infrastructure with a $\mathrm{D}+$ and estimated that an additional $\$ 178$ billion in annual funding would be required to "significantly improve conditions and performance" (ASCE 2013). These statistics, among others, have prompted a number of decision makers to initiate discussions and take action to address shortfalls in funding transportation infrastructure.

Embedded within many of these discussions is the impact that alternative fuels and advanced vehicle technologies (which support separate, but no less important, economic and environmental policy objectives than the HTF) will have on funding our transportation infrastructure. The increase in the use of alternative fuels and more stringent federal fuel economy standards will exacerbate revenue shortfalls. The extent of this impact is highly contingent on a number of peripheral factors (i.e., markets, technology, policy, and regulation). Regardless of the exact impact, it is becoming increasingly clear that the current system of taxing motor fuels does not properly account for the array of technology options that are now available to consumers. The effect inherently favors some fuels and technologies over others and can stack otherwise aligned policy objectives against one another.

As vehicle technologies and fuels have evolved, states have responded in various ways, but general inconsistencies in motor fuel tax policies among federal and state governments, along with inherently inefficient substitute fees, have created market barriers for the increased adoption of alternative fuels by creating a patchwork regulatory framework. Furthermore, the emergence of the ability to economically charge or fuel a vehicle at home has given rise to an increasing subset of transportation system users that motor fuel taxes do not capture. This calls into question the ability of the current revenue framework to be effective in achieving fair and equal taxation. To tackle these challenges, the perspectives of a number of stakeholders will need to be engaged to develop solutions that consider how to balance parity across fuels and technologies, funding transportation infrastructure, and the reduction of petroleum consumption and vehicle emissions.

For some near-term perspective, the taxation of fuel-efficient and alternative fuel vehicles (AFVs) will not begin to solve our nation's infrastructure funding issues. Hybrid vehicles and 
vehicles capable of running on an alternative fuel or electricity account for roughly $10 \%$ of the 210 million light-duty vehicles sold since 1999 (Polk 2015), and petroleum accounts for 96\% of our annual transportation fuel use as a nation. Owners and operators of medium- and heavy-duty vehicles, which account for $29 \%$ of petroleum used in over-the-road transportation (EIA 2015a), are increasingly looking to alternative fuels as a cost saving measure; however, these vehicles are expected to predominantly use petroleum-based diesel fuel over the next 10 years (Fuels Institute 2013).

Conversely, the broader discussion of funding transportation infrastructure has the potential to significantly affect the market for alternative fuels and high-efficiency vehicles in a way that can either hinder or strengthen efforts to reduce petroleum consumption and greenhouse gas emissions. This report intends to provide an overview of motor fuel taxation, review its specific relationship to alternative fuel use and vehicle efficiency, and outline approaches that a number of states have taken to address these issues. The specific focus is on motor fuels used in over-theroad transportation, which accounted for approximately $82 \%$ of all energy used for transportation in the United States in 2014 (EIA 2015a). The report primarily provides context around federal fuel tax rules and rates, but analogies can be drawn to individual state programs. 


\section{Background on Motor Fuel Taxes}

\subsection{An Abridged History of Motor Fuel Taxes and Highway Funding Mechanisms}

Shortly after vehicles were introduced to the consumers in the early 1900s, policymakers began to examine ways to support a public infrastructure that would be required by their growing popularity. Since then, a number of fees and taxes have been put in place, which have primarily been levied directly against vehicle owners and drivers. In the current system, revenues for transportation infrastructure are generated through a combination of local, state, and federal programs and the mechanisms for doing so vary widely across and among jurisdictions. Figure 1 shows the aggregate and relative contributions made by federal, state, and local governments toward highway funding (contributions vary among individual states and local jurisdictions). Funds collected by states account for about half of all highway funding.

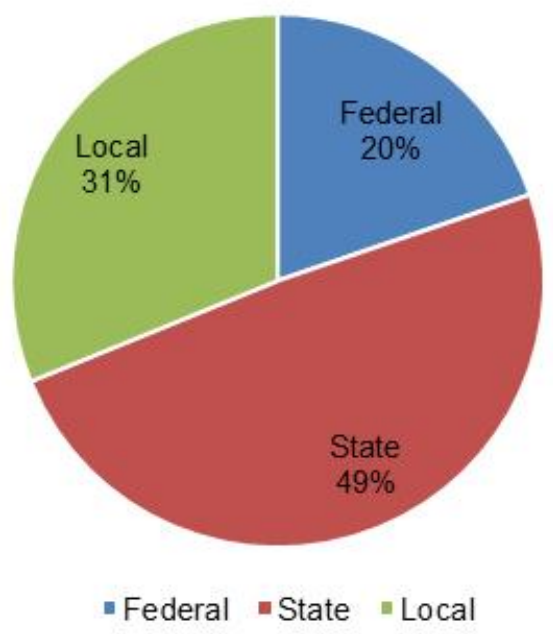

Figure 1. National highway funding contribution by source (2012). Source: FHWA 2014a.

\subsubsection{The Advent of State Motor Fuel Excise Taxes}

States were the first to take action on creating a mechanism to fund the construction and maintenance of a public road network when Oregon adopted a \$0.05/gallon tax for gasoline sold within the state in 1919. Other states quickly followed Oregon's lead, and within 10 years, all states had some form of a gasoline tax. The tax that was put in place in Oregon (and many other states) is known as an excise tax, which is a tax levied on the manufacture, sale, or consumption of a commodity. In the case of motor fuel, the unit that the excise tax is levied against is often a gallon of fuel. Excise taxes are often directly embedded into the price of a product or service. While most states use this approach, other mechanisms have been implemented as a substitute or supplemental revenue source.

\subsubsection{State Registration Fees, Sales Taxes, and Other Sources of Transportation Revenue}

Mechanisms such as registration fees, user fees, tolls, and sales taxes have been put into place to provide alternative or additional revenue to motor fuel excise taxes. In some cases, this includes specific fees for AFVs that are intended to replace and/or supplement revenue that existing motor 
fuel taxes cannot capture for these vehicles (for reasons to be covered later). With a few exceptions, these fees and taxes are levied in addition to excise taxes. A study by the National Conference of State Legislatures indicated that seven states charge a designated sales tax that is levied on gasoline and diesel fuel (California, Florida, Georgia, New York, Tennessee, Vermont, and West Virginia) ${ }^{1}$; seven states subject motor fuels to the general sales tax (California, Florida, Georgia, Hawaii, Illinois, Indiana, and Michigan); and seven states collect taxes from fuel distributors or suppliers (Connecticut, Hawaii, Nebraska, New Jersey, New Mexico, New York, and Pennsylvania). Most of these states dedicate a substantial portion of these revenues to transportation infrastructure (Workman and Rall 2012).

Many states and local governments have also put in place mechanisms to generate revenue to pay for transportation infrastructure through various other indirect revenue programs such as severance taxes, incomes taxes, and the sale of advertising and concessions at public facilities. Figure 2 shows the average contributions of various funding mechanisms by source. Revenues collected directly from users are by far the dominant form of revenue for states that support highways. Note that not all of these revenue streams are solely dedicated to transportation expenditures.

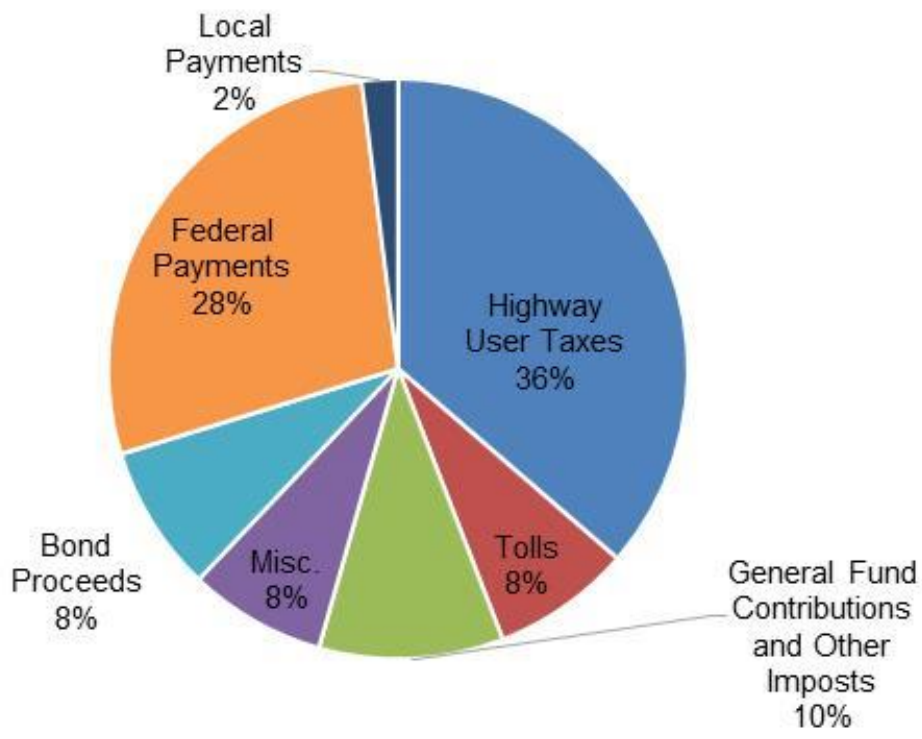

Figure 2. Distribution of aggregate sources of state highway funding by type (2012). Source: FHWA 2014b.

While user-collected fees, and specifically motor fuel taxes, are the most common source of revenue for transportation infrastructure, there is wide variation among states on the rates charged and the approach to taxing the two dominant sources of transportation energy: gasoline and diesel. The maps in Figure 3 and Figure 4 provide detailed information on the cumulative taxes levied against gasoline and diesel fuels, illustrating the wide variety of rates and mechanisms employed across the 50 states. It is important to note that federal taxes are considered in all of these rates and that the relative level of variation among states is solely a reflection of state taxes and fees.

\footnotetext{
${ }^{1}$ In several states, these "sales taxes" more closely mirror an excise tax in that they are indexed at set intervals within predetermined limits.
} 


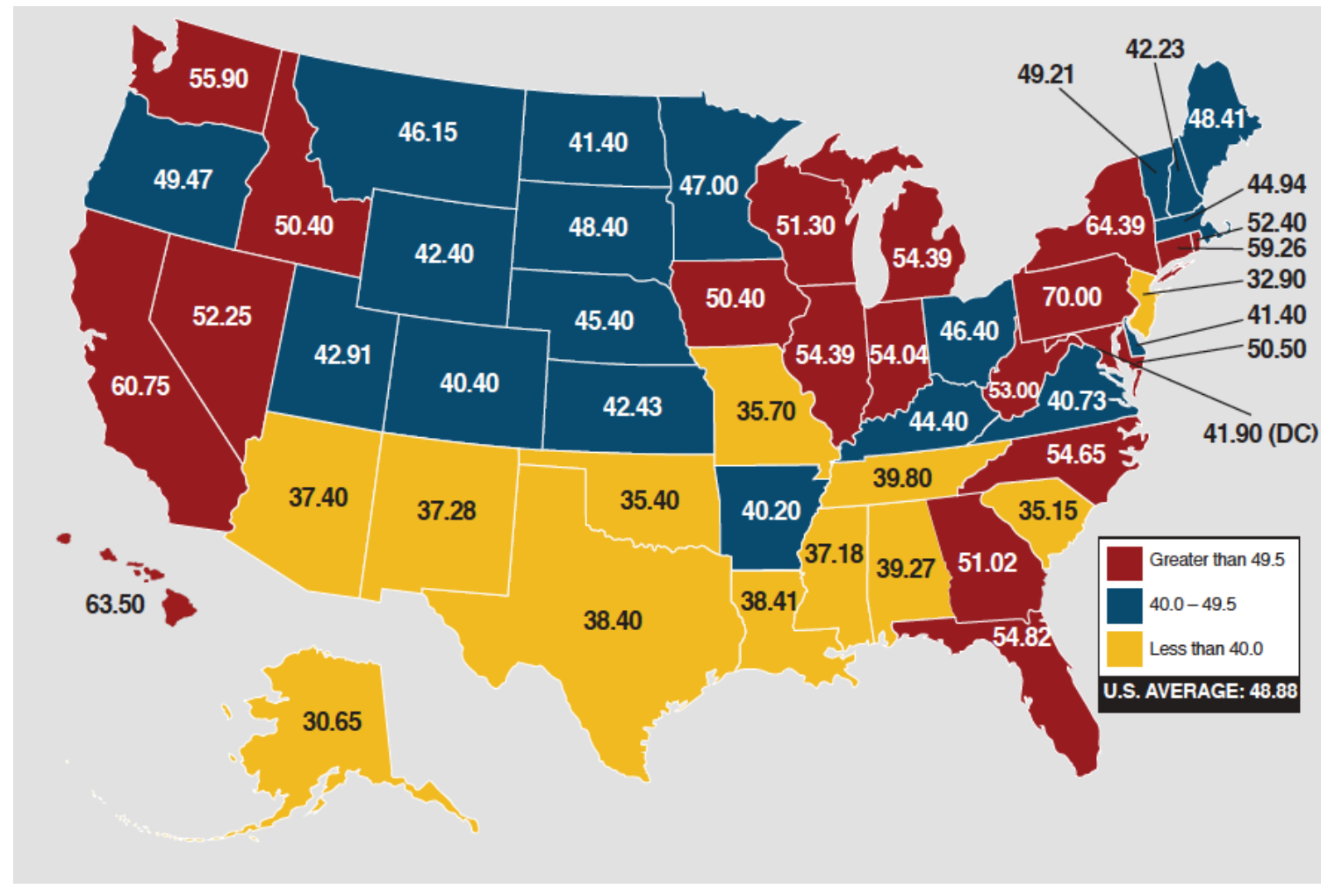

Figure 3. Cumulative state and federal gasoline taxes in cents (July 2015). Source: API 2015a.

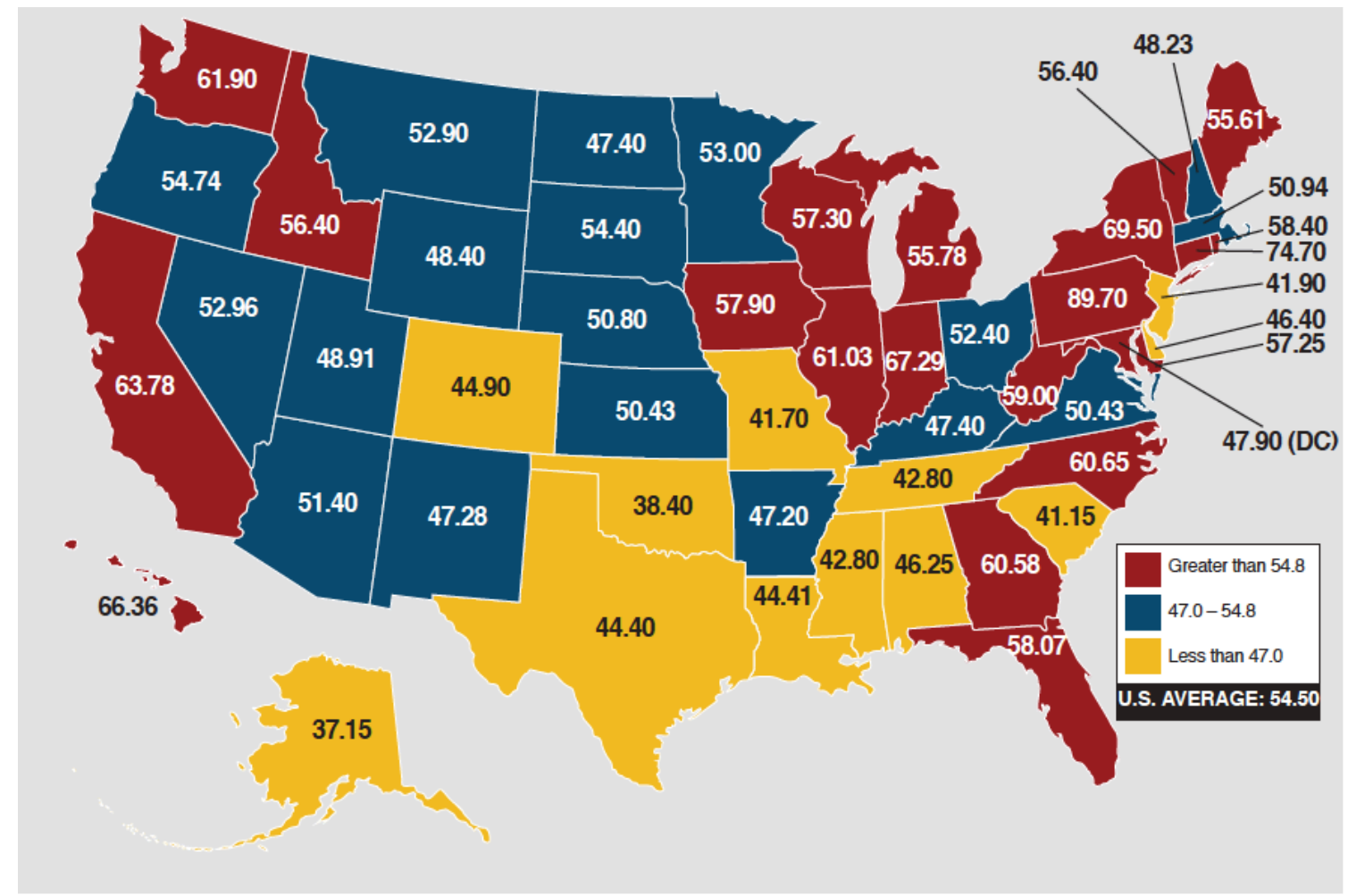

Figure 4. Cumulative state and federal diesel taxes in cents (July 2015). Source: API 2015b. 


\subsubsection{Federal Motor Fuel Taxes}

While states took initial action in establishing motor fuel taxes, similar federal taxes were not put in place until the Revenue Act of 1932. The first federal gas tax was part of a sweeping set of reforms that were aimed at addressing the fiscal issues that stemmed from the Great Depression. While initially proposed as a tax on imported fuel, the final legislation established a $\$ 0.01 /$ gallon excise tax on all gasoline sales, which refiners would collect. Revenue collected by the gas tax supported the general fund of the federal budget until the creation of the HTF established a direct allocation of revenue to infrastructure. The Federal-Aid Highway Act of 1956 appropriated $\$ 25$ billion to fund the construction of 41,000 miles of interstate highway, which, at the time, was the largest public works project in U.S. history (Weingroff 1996). ${ }^{2}$

In the 1980s, Congress raised the gas tax for the first time since 1959 through two legislative actions. The first of these bills, passed in 1982, established additional accounts under the HTF that fund mass transit and the remediation of underground storage tanks; these accounts still exist today. Congress increased fuel taxes again in 1990 with the additional revenue directed toward deficit reduction. In 1993, Congress established the current rates for motor fuel taxes, increasing the tax rate for gasoline to $\$ 0.184$ /gallon and $\$ 0.244 /$ gallon for diesel, again dedicating the increases to deficit reduction. ${ }^{3}$ Changing course from previous actions to utilize motor fuel taxes as a deficit reduction strategy, in 1997 Congress declared that all revenue collected from motor fuel taxes would again go exclusively to the Highway Trust Fund. Since 1997, the HTF has remained largely in its current state with continued short-term reauthorizations keeping the program in place. Figure 5 summarizes changes in federal gasoline excise tax rates since their inception in 1932.

Despite a continuous debate among federal, state, and local officials and multiple opportunities for the federal motor fuels tax to expire, motor fuel taxes remain the primary mechanism for funding transportation infrastructure; however, recently the balance in the HTF has proven to be insufficient to meet demands.

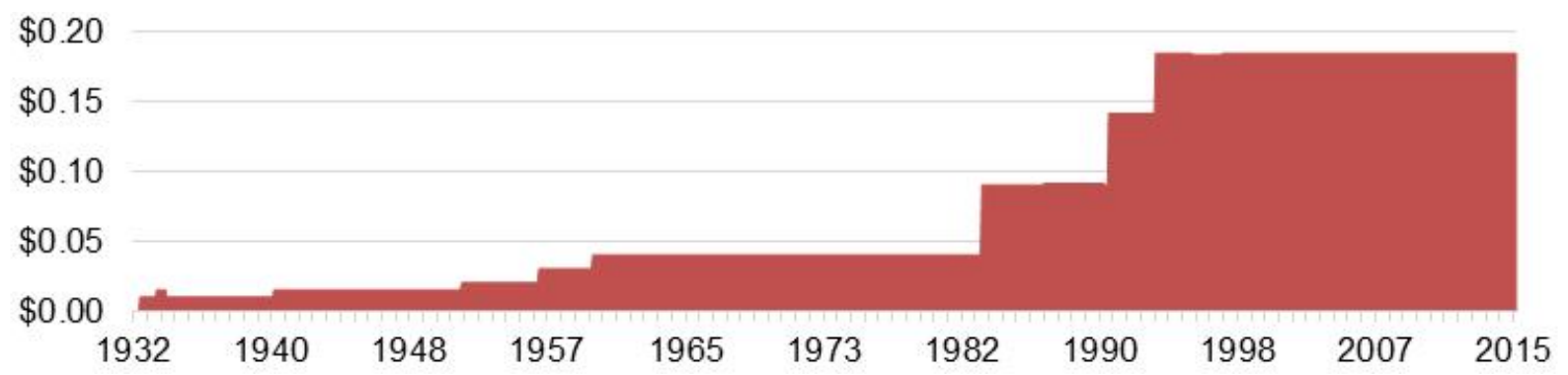

Figure 5. Federal Gasoline excise tax rates (1932-2015). Source: Lowry 2015.

\footnotetext{
${ }^{2}$ Note that some of the revenue also was used for deficit reduction at the time.

${ }^{3}$ According to a report by the Congressional Joint Committee on Taxation, diesel is taxed at a greater level than gasoline because "Congress concluded that the higher rates scheduled to take effect under the Highway Revenue Act of 1982 have imposed a large tax on trucking operations, which did not necessarily relate to the amount of business they might do, and that an alternative form of highway excise taxation should be devised, which is more definitely correlated with the use of trucks. Therefore, Congress decided to substitute a higher diesel fuel tax for a lower use tax" (Joint Committee on Taxation Staff 1984). While the diesel tax is greater than gasoline tax at the federal level, this is not always true in states. There are a number of factors that determine how Congress taxes these two fuels relative to each other.
} 


\subsection{The Current State of the HTF: Rising Costs and Decreasing Revenues}

As the previous section illustrates, motor fuel taxes have served a variety of roles in creating revenue for the federal government. Initially, the federal government envisioned that fuel taxes would be a tool to raise general revenue. In 1956, the HTF established a dedicated funding source in which motor fuel taxes directly supported the construction and maintenance of transportation infrastructure. In the 1980s and first half of the 1990s, Congress even utilized motor fuel taxes to generate a surplus that would reduce the nation's budget deficit. In 2008, however, Congress began transferring general funds from the U.S. Treasury to the HTF. This transfer has happened several times since totaling a contribution of $\$ 41$ billion (Cawley 2013). In other words, federal motor fuel taxes and the Highway Trust Fund have oscillated between being a general revenue source and a dedicated and supplemental funding stream for infrastructure. In its current form, the HTF is projected to become insolvent pending additional extensions. A 2013 report by the $\mathrm{CBO}$ has projected that the $\mathrm{HTF}$, a revenue generator 20 years ago, will have a budget shortfall of $\$ 92$ billion by 2025, as shown below in Figure 6 .

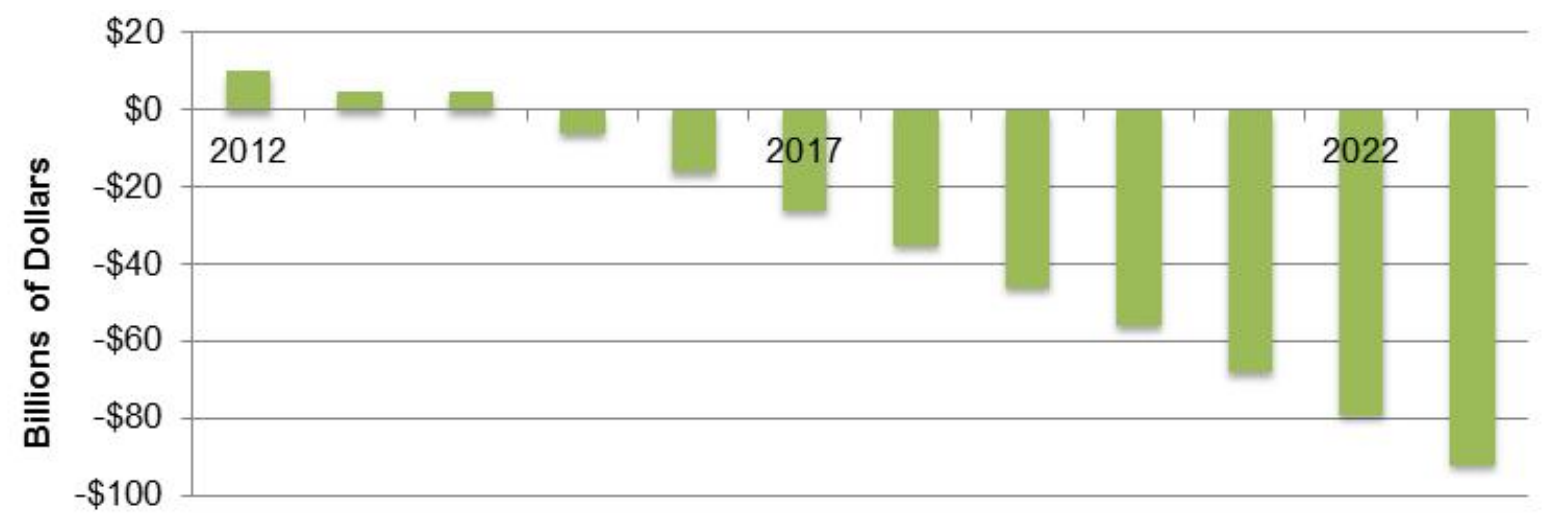

Figure 6. Projections of the Highway Trust Fund balance (2012-2025). Source: Dinan and Austin 2012.

A thorough examination of the events and factors behind this shift is outside the scope of this report, but the two causes most often cited are (1) static fuel taxes' inability to keep pace with costs due to inflation and other factors and (2) an increase in vehicle fuel efficiency. A study by the Institute of Taxation and Economic Policy found that the "purchasing power" of motor fuel taxes has decreased by $28 \%$ since 1997 (ITEP 2013). The study demonstrates that increases in road maintenance and construction costs have had a much more dramatic effect in decreasing purchasing power than the increase in vehicle efficiency.

Decreases in highway funding also can be attributed to the recent decline on overall gasoline and diesel sales. Figure 7 shows that U.S. fuel consumption peaked in 2006, and while there have been isolated year-over-year increases in consumption since then, demand has remained relatively flat overall. 


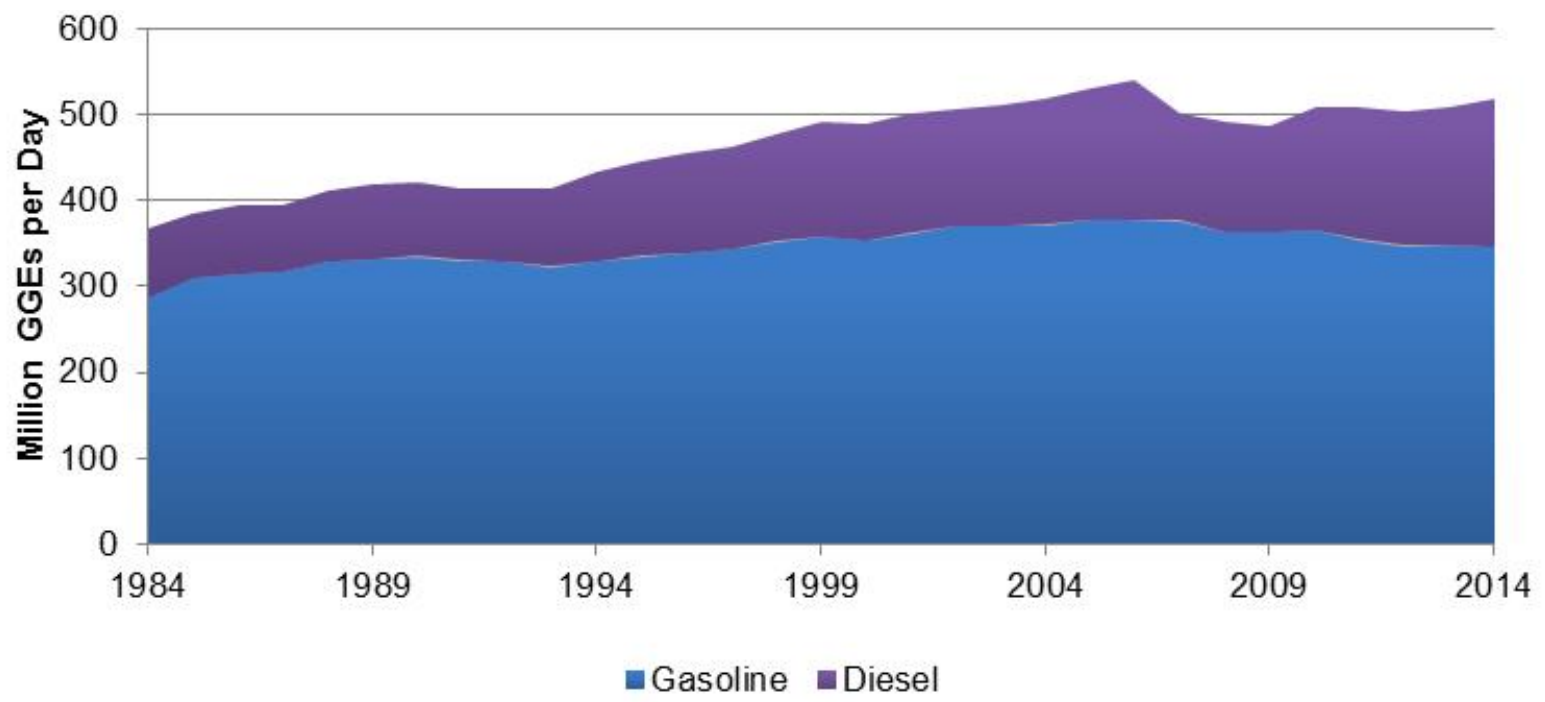

Figure 7. Cumulative gasoline and diesel consumption in gasoline gallon equivalents (1984-2014). Source: EIA 2015b.

\subsection{The Mechanics of Motor Fuel Taxes}

As an excise tax, motor fuel taxes usually are factored into the prices posted on retail fueling station signs and at individual fuel dispensers. While the consumer ultimately pays the fuel tax at the dispenser, the tax is often levied upstream of that transaction. In the case of federal taxes, the Internal Revenue Service (IRS) collects taxes from the importer or refiner of the finished product (i.e., gasoline or diesel). Estimated revenues are transferred into the Highway Trust Fund on a monthly basis and later adjusted based on actual sales. At the state level, the point of collection for gasoline and diesel taxes varies, but it is often at either the distribution or terminal level (see Figure 8 for a more detailed illustration of the supply chain for gasoline and diesel). However, often retail outlets collect taxes on alternative fuels, such as natural gas and propane, directly from the consumer. In any case, the fuel tax that ultimately is levied is often composed of federal, state, and sometimes local components.

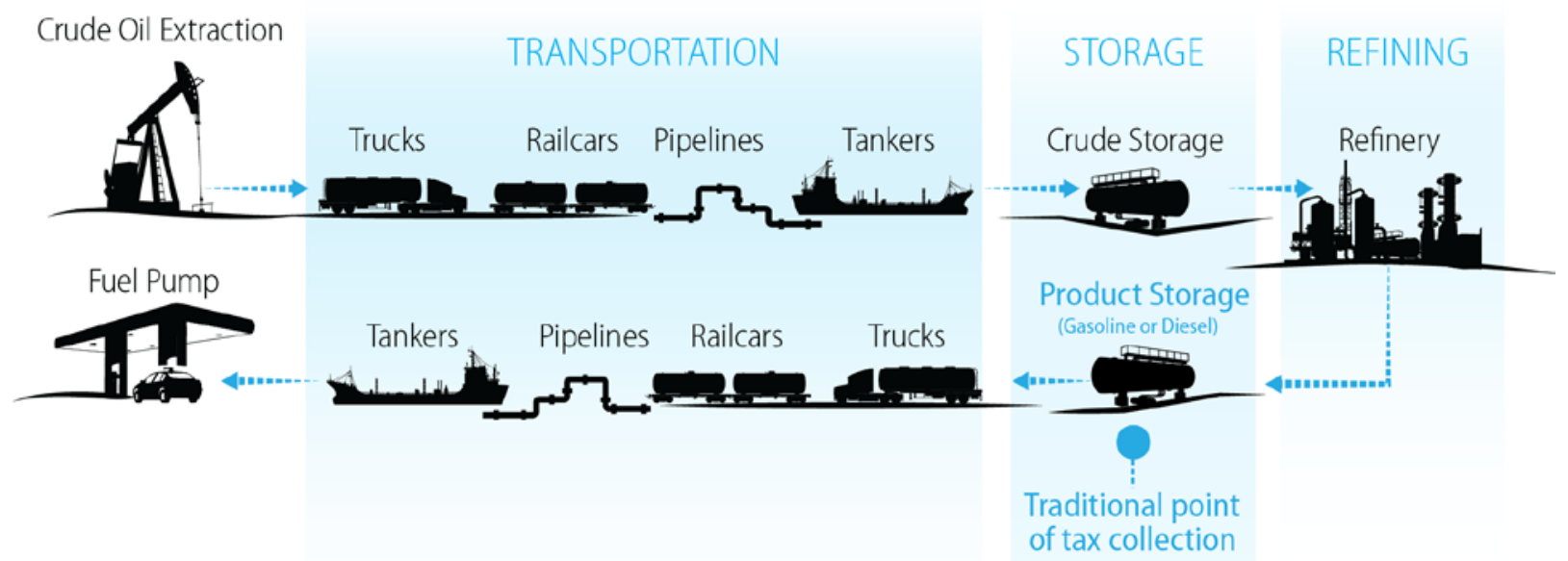

Figure 8. Gasoline and diesel production supply chain. 


\subsubsection{Remittance of Fuel Taxes for Interstate Carriers}

With the variation in fuel tax rates among states, a separate accounting structure has been established for vehicle fleets that operate across multiple states to remit fuel taxes. The inherent business of interstate motor carriers creates a situation in which a fueling transaction could take place in a state separate from where a majority of VMT occurred. The effect is that a given state's revenues from motor fuel taxes could be disproportionate with the impact vehicles have on its infrastructure.

To address this, the International Fuel Tax Agreement (IFTA) was created in 1991 to simplify state-level transactions and create a system for distributing revenues. It currently includes the 48 contiguous U.S. states and 10 Canadian provinces as parties to the agreement. Vehicles that operate in multiple states and meet one of the following conditions qualify for an IFTA license:

- Two axles and a gross vehicle weight (or registered gross weight) exceeding 26,000 pounds

- Three or more axles, regardless of weight

- Used in a combination configuration (i.e., tractor and trailer), and the gross vehicle weight of the combination is more than 26,000 pounds.

Carriers in IFTA jurisdictions are required to obtain an IFTA license; alternately, in some cases, carriers can obtain trip permits if interstate travel occurs infrequently. Fuel taxes are reported on a quarterly basis through IFTA and allow a carrier to report taxable miles, gallons of fuel, and taxes paid in order to reconcile discrepancies across states. It is important to note that IFTA is solely a coordinating entity, as its functions are purely administrative and do not influence state motor fuel tax rates.

\subsection{Motor Fuel Tax Exemptions}

In many cases, government agencies and other designated entities (such as some transit providers) are exempt from motor vehicle and fuel taxes such as excise taxes, sales taxes, or vehicle registration fees. Additionally, certain fuels used primarily for non-road applications, such as kerosene, are also exempt. Dyed diesel, which is dyed red to allow for verification, is used by governments and in farm equipment and is exempt from fuel taxes in many cases. ${ }^{4}$ For detailed information on state-by-state exemptions, visit the Federal Highway Administration website at www.fhwa.dot.gov/motorfuel/sales taxes_exemptions.htm.

\subsection{Remitting Federal Taxes on Alternative Fuels}

Because of basic differences in how alternative fuels are produced and transported to market, taxes on these fuels are often remitted further downstream in the supply chain than gasoline and diesel taxes. In most cases, taxation of alternative fuels occurs when a motor fuel is dispensed into a vehicle (generally at a retail or private fueling facility), which can affect compliance mechanisms and burdens. ${ }^{5}$ Federal taxes are submitted directly to the IRS on at least a quarterly basis. State compliance programs, and the methods and schedules of payment specified therein, vary from one state to the next, but most use forms that follow a format similar to that of the IRS.

\footnotetext{
${ }^{4}$ Several states tax dyed diesel. Those that do, often tax it at a reduced rate.

${ }^{5}$ There is an exception to this rule at the federal level that allows the excise tax to be paid upstream of the end-use transaction when a fuel is purchased in bulk quantities.
} 
Table 1 shows the federal rates for excise taxes on alternative fuels (as defined by the federal Energy Policy Act of 1992), which are shown on a per-gallon basis for liquid fuels. ${ }^{6}$ Compressed natural gas $(\mathrm{CNG})$ is measured in gasoline gallon equivalents (GGEs), defined by the IRS as 5.66 pounds or 126.67 standard cubic feet of natural gas (US IRS 2013a). ${ }^{7}$ Low-level ethanol blends (also referred to as gasohol by the IRS) are taxed at a rate equivalent to gasoline and biodiesel is taxed as diesel fuel regardless of the blend level.

Table 1. Federal Motor Fuel Excise Tax Rates. Source: US IRS 2015.

\begin{tabular}{lc}
\hline \multicolumn{1}{c}{ Fuel } & Tax Rate Per Gallon (cents) \\
\hline Gasoline & 18.4 \\
Ethanol/Methanol & 18.4 \\
Diesel and Kerosene & 24.4 \\
Biodiesel & 24.4 \\
Liquefied Petroleum Gas (LPG) & 18.3 \\
(propane, butane, pentane, or mixtures of these & \\
gases) & \\
Liquefied Natural Gas (LNG) & 24.3 \\
Compressed Natural Gas (CNG) & 18.3 \\
P-Series Fuels & 18.4 \\
Liquefied Hydrogen & 18.4 \\
Any liquid fuel derived from coal through the & 24.4 \\
Fischer-Tropsch process & \\
Ethanol Produced from Natural Gas & 11.4 \\
Methanol Produced from Natural Gas & 9.25 \\
Other Fuels & 18.4 \\
\hline
\end{tabular}

States have various rates and methods of defining alternative fuels, which are discussed in more detail later. IFTA's reporting accommodates alternative fuels and characterizes them as "use fuels." However, state alternative fuel excise tax rates are not necessarily consistent with one another or with the federal rates shown above, which can create a growing challenge as alternative fuel use increases.

\footnotetext{
${ }^{6} \mathrm{CNG}, \mathrm{LNG}$, and LPG do not pay the $\$ 0.001$ underground storage remediation fuel that the others do.

${ }^{7}$ As discussed in more detail later, other jurisdictions use different values for a gasoline gallon equivalent (GGE) of CNG.
} 


\section{The Growing Role and Complications of Alternative Fuels and Advanced Vehicle Technologies}

\subsection{Growth in Alternative Fuel Use and Vehicle Availability}

While motor fuel taxes were not officially put in to place until 1919, ethanol, which was primarily used as a fuel for lighting at the time, was taxed at a price of \$2/gallon in 1862 as part of a tax on alcohols levied to pay for the Civil War (Carolan 2009). Congress repealed the tax in 1906, making ethanol a competitive alternative to gasoline and some of the world's first automobiles were designed to run on ethanol. Electric and steam-powered vehicles were also commonplace in the early 1900 s. In 1903 , only $27 \%$ of the vehicles registered in New York were powered by gasoline, while 53\% were steam powered, and $20 \%$ were electric vehicles (Wakefield 1994). ${ }^{8}$

During the 1920s, however, gasoline began to establish a foothold as the fuel of choice as the supply of low-cost crude oil increased. The number of drive-in fueling stations grew from 12,000 in 1921 to 143,000 in 1929 (Drowne and Huber 2004). By the time the first federal motor fuel tax was implemented, gasoline had emerged as the dominant fuel for transportation in the United States. Gasoline's market share had grown even larger by 1956, when the nation's transportation infrastructure was expanded and Congress created the Highway Trust Fund.

While diesel and gasoline still account for greater than $96 \%$ of the energy used to fuel the nation's highway transportation activities, ${ }^{9}$ the availability of alternative fuels and more efficient vehicles has been substantively increasing in recent years. Technological advances, market forces, and public policy have greatly expanded the diversity of vehicles. While AFVs still make up a relatively small portion of the nation's total fleet, as show in Figure 9, their market presence is increasing.

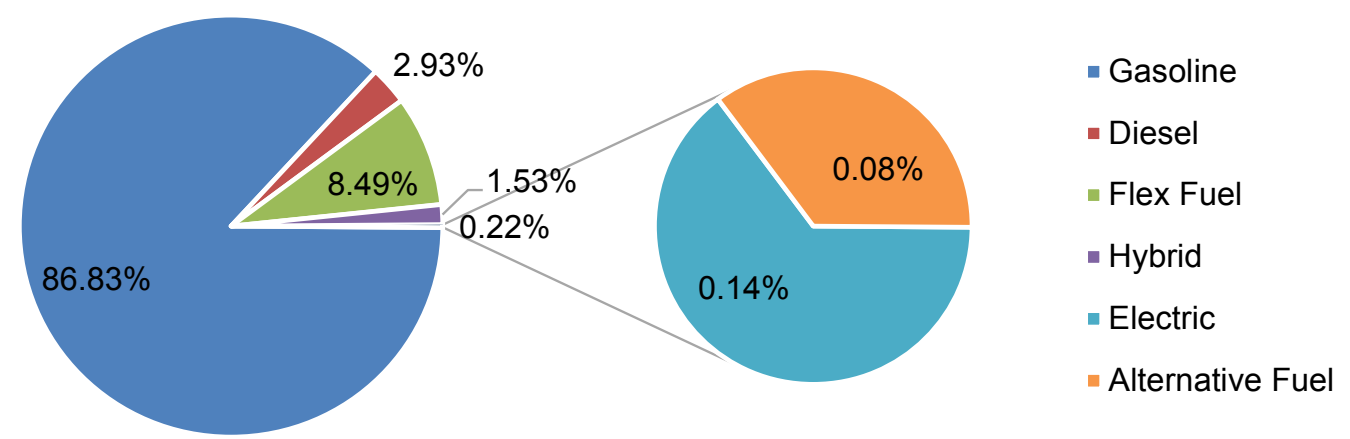

Figure 9. Approximate number of gasoline, diesel, hybrid, electric, and alternative fuel light-duty vehicles (model years 1999-2015). Source: Polk 2015. ${ }^{10}$

\footnotetext{
${ }^{8}$ Steam-powered vehicles relied on water and a number of liquid fuels to produce steam.

${ }^{9}$ Low-level ethanol blended with gasoline is not included in this statistic. Adding ethanol back in would yield a value greater than 99\%. Calculations were derived from Tables 2.4 and 2.5 in the Transportation Energy Data Book, $32^{\text {nd }}$ Edition.

${ }^{10}$ Alternative fuel vehicles include those that are capable of running on natural gas and propane or have been upfitted by the manufacturer for possible conversion to these fuels.
} 
Since 1991, when the U.S. Department of Energy (DOE) began publishing a guide of available alternative fuel vehicles, the number of alternative fuel and hybrid electric vehicle models has increased from two to 191 in 2015 (DOE 2015). Figure 10 shows year over year increases in alternative fuel, electric, and hybrid vehicle availability.

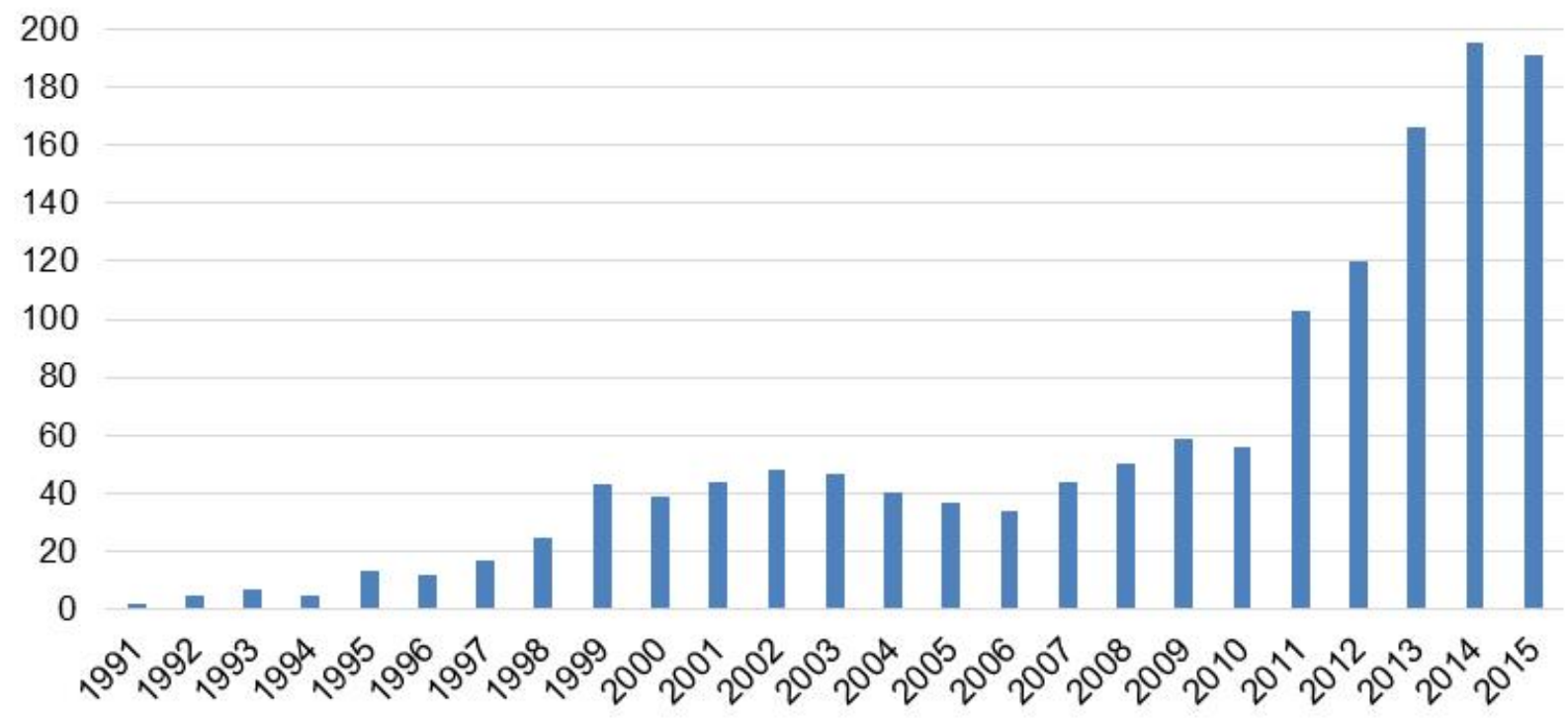

Figure 10. Alternative fuel, electric, and hybrid vehicle light-duty vehicle models by year. Source: DOE 2015.

Many alternative fuel vehicles use liquid or gaseous fuels; however, newer vehicle models allow for electricity, which can be generated off-board of the vehicle and used to power driving. These fuels and power sources are not exclusive in an individual vehicle and often exist in combination. Some vehicles are capable of running on multiple fuels at once (dual-fuel), others can choose between fuels (bi-fuel), and a third option allows the use of an alternative fuel blended into gasoline in varying proportions (flexible fuel).

A hybrid electric vehicle runs on gasoline but achieves fuel efficiency advantages by employing a small electric motor that uses energy stored in a battery; the internal combustion engine and regenerative braking charges the battery. Plug-in electric vehicles (PEVs) draw electricity from an off-board power source to charge their batteries. Of these vehicles, some run on both gasoline and electricity (plug-in hybrid electric vehicles, or PHEVs), and others run purely on electricity (all-electric vehicles). Recently, automakers also have begun making fuel-cell electric vehicles available to consumers, which generate electricity on board from hydrogen, which is stored and dispensed as a compressed gas.

\subsection{Challenges with Alternative Fuels and Advanced Technologies Under the Current System of Motor Fuel Excise Taxes}

The historical and current system of collecting motor fuel taxes exists with the understanding that gasoline and diesel will be the primary fuels in over-the-road transportation and that fueling will be conducted at central (often retail) locations. Given the expanding array of fuels and vehicle technologies available, parity and enforcement challenges have arisen. Challenges related 
to alternative fuels and advanced vehicle technologies that the current system of motor fuel taxes is not equipped to address adequately include:

- Increased vehicle efficiency

- More stringent vehicle emissions standards that promote technologies not subject to motor fuel taxes

- Taxation bias against some fuels on energy-content basis

- Inconsistency in weights and measures among state and federal entities

- Opportunities for non-retail (home or workplace) charging and fueling activities.

In response to these challenges, many state lawmakers and regulators have revised motor fuel taxes to allow for revenue to be collected on the use of alternative fuels and in some cases, make up for revenue lost by increases in vehicle efficiency and electrification. The following provides an overview of some key issues proposed to address these challenges.

\subsubsection{Increased Vehicle Efficiency and Reduced Vehicle Miles Traveled}

Motor fuel tax revenues at the state and federal levels are directly tied to the number of gallons of gasoline and diesel fuel sold in a given year, which in turn creates an inverse relationship between fuel tax revenues and vehicle fuel efficiency. In other words, the fewer gallons of fuel a vehicle needs to travel the same distance, the lower the relative contribution that vehicle makes to the Highway Trust Fund. Policy or other decisions related to motor fuel taxes and vehicle fuel efficiency are inextricably linked in a way that can potentially lead to uncomfortable trade-offs between funding infrastructure and the efficient use of natural resources.

Corporate Average Fuel Economy (CAFE) standards have been in place since 1978 and require increased fuel economy for new vehicles at rates shown in Figure 11. As the figure shows, these standards have increased dramatically in recent years and will reach 54.5 miles per gallon by 2025. Complementing this policy are new fuel efficiency standards for medium- and heavy-duty vehicles, which also set targets through 2025.

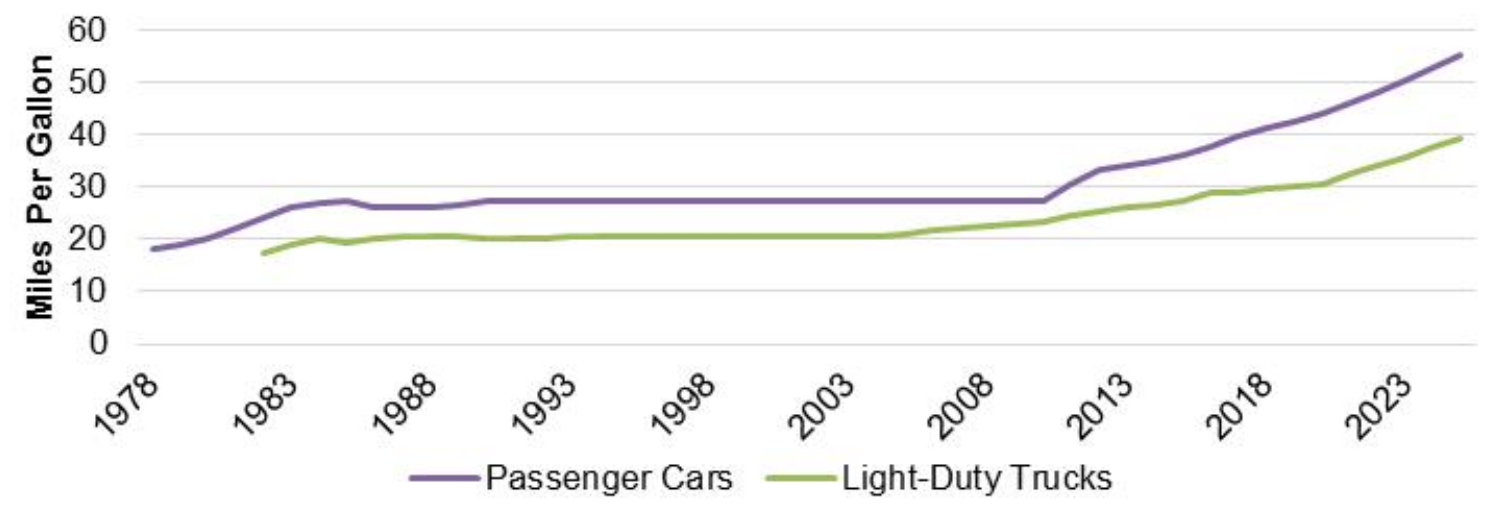

Figure 11. Light-duty Corporate Average Fuel Economy (CAFE) standards by year. Source: DOE 2013. 
Between 1997 and 2013, the purchasing power of motor fuel taxes has decreased by $28 \% ; 6 \%$ is attributed to increased vehicle efficiency standards and $22 \%$ is attributed to increases in construction costs (ITEP 2013). However, moving forward, the impacts of light-duty efficiency standards are likely to have a larger impact. The CBO projects that by 2040 , gasoline consumption will decrease from 196 billion gallons a year to 155 billion gallons per year due to CAFE standards (a decrease of $21 \%$ ), leading to a proportional reduction in fuel tax revenue over that time if fuel tax rates remain unchanged. ${ }^{11}$ State motor fuel tax revenues will exhibit a similar effect, except in those that have alternate methods for determining rate, such as indexing fuel taxes to fuel prices. The heavy-duty efficiency standards referenced earlier will further exacerbate this impact. While CAFE standards will have positive impacts on reducing per vehicle petroleum consumption and lessening environmental impacts, revenue provided to the HTF will decrease on a per vehicle basis.

Compounding the impacts of increased vehicle fuel efficiency is the recent trend of stagnant or decreasing total VMT, as shown in Figure 12. If fuel savings are greater than the incremental purchase cost of a more efficient vehicle, increased efficiency makes driving an overall cheaper proposition. This phenomenon, known as the "rebound effect," can actually lead to people driving more, which could potentially offset the revenues lost through increased vehicle efficiency (Greene, Kahn, and Gibson 1999). ${ }^{12}$ While this trend has held true for a number of years, recent data suggests that increased vehicle efficiency has actually corresponded with a relative decrease in VMT, which exacerbates the decrease in revenues from motor fuel taxes.

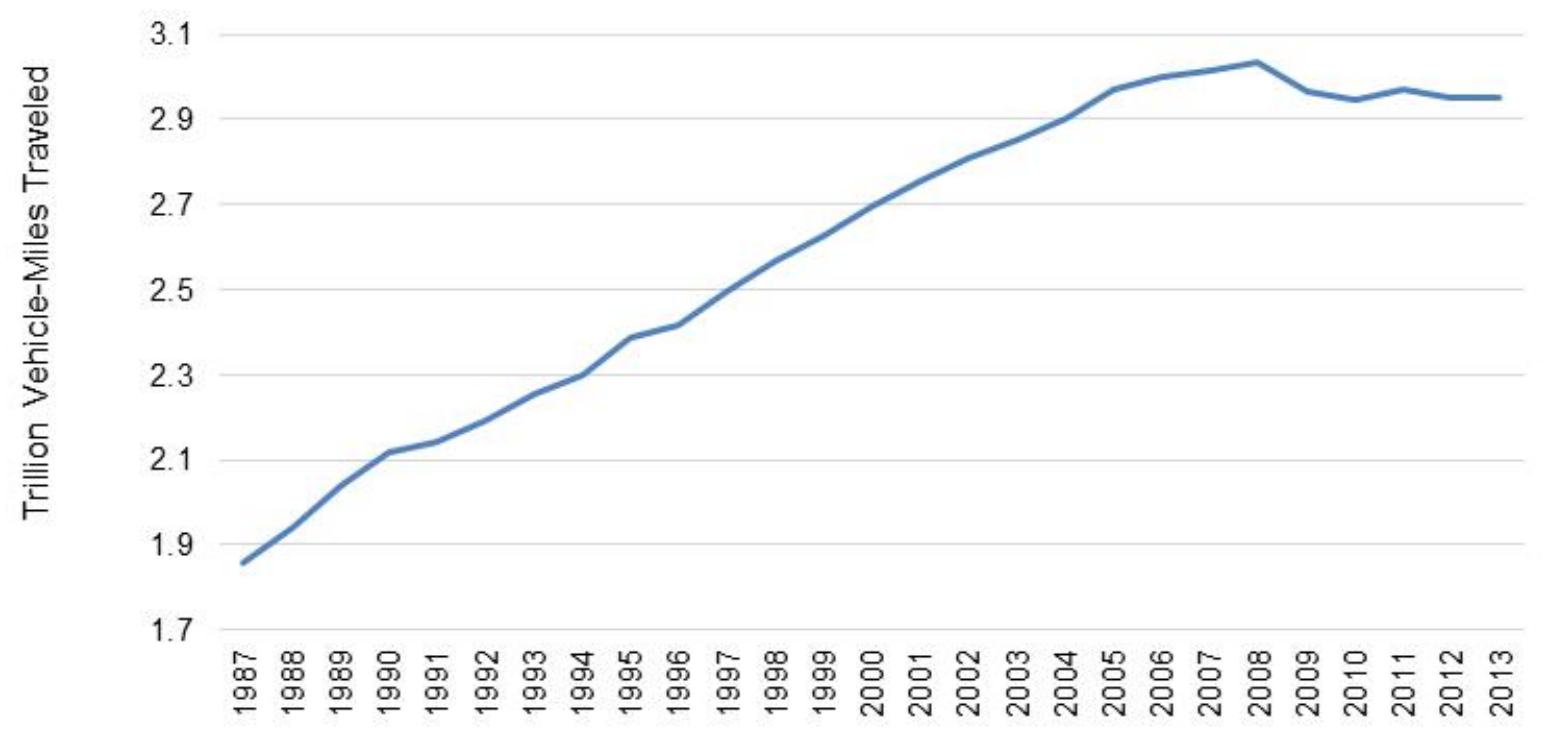

Figure 12. Twelve-month rolling average of vehicle miles traveled in the U.S. Source: FHWA 2013a.

\footnotetext{
${ }^{11}$ This assumes that CAFE standards will not get more stringent after model year 2025. The CBO chose the year 2040 to allow time for high-efficiency vehicles to enter the national fleet in greater numbers. CBO builds off projections by the U.S. Environmental Protection Agency (EPA) and includes targets in the Renewable Fuel Standard.
} 


\subsubsection{Emission Regulations}

Complementary to CAFE standards, the California Air Resources Board (CARB) Zero Emission Vehicle (ZEV) mandate seeks to increase vehicle efficiency and reduce emissions through a targeted effort to get vehicles with zero emissions on the road. This effort will have an additional impact in reducing fuel tax revenues collected from gasoline and diesel consumption. Given that tailpipe emissions are inherent to vehicles with internal combustion engines, it is unlikely that many, if any, of the required zero-emission vehicles will utilize traditional motor fuels or those that fall under the current taxation regime. ${ }^{13}$ Instead, the expectation is that these vehicles will be electric drive vehicles that will generate electricity onboard from hydrogen or use stored electricity generated by the power grid. Currently, neither hydrogen nor electricity are explicitly included in federal or state motor fuel taxes, nor are they fully included in many state registration fees or decal programs.

California is requiring that $22 \%$ of vehicles sold by major automobile manufacturers produce zero emissions by 2025 (CARB 2012). Nine other states have exercised the option of adopting this standard as well; they include Connecticut, Maine, Maryland, Massachusetts, New Jersey, New York, Oregon, Rhode Island, and Vermont. If all these states adopt California's standard, it's projected that up to 800,000 light-duty zero emission vehicles would need to be sold annually by the automakers by 2025 (O’Dell 2012).

\subsubsection{Energy-Content Penalty}

The current system of taxing motor fuels is structured around the purchase of either a gallon of gasoline or diesel fuel. Without proper conversion factors, fuel taxation via these two units of measurement fails to account for variation among alternative fuels, some of which are gaseous (and therefore not constrained by volume) and each of which has a unique energy density.

The current methodology of calculating fuel taxes based on volume inconsistently values the energy density, or energy content of the fuel. For a given variety of fuels, a vehicle will travel varying distances on a gallon of those fuels dependent on their energy content. This would suggest that energy content is a more accurate per-unit measure of the impact a vehicle has on roads and would be a logical basis for calculating fuel tax across the increasing variety of fuels that are being used.

Table 2 shows the average energy content in a gallon of several common alternative fuels (compressed natural gas is shown in BTU/cubic foot) as well as a BTU-based GGE for each of these fuels. A gasoline gallon equivalence of greater than one indicates that there is more energy in one gallon of that particular fuel than gasoline, where a gasoline gallon equivalence of less than one indicates that the fuel has a lower energy density than gasoline. The fourth column of the table shows the current federal tax rate per volumetric gallon of a particular fuel, followed by the effective rate per 100,000 BTU of energy. While some of these fuels are more likely to be used as substitutes for diesel rather than gasoline, the analysis shows that in either case, most users of alternative fuels pay a higher per-BTU tax rate under the current federal tax structure than do users of gasoline or diesel. (A similar analysis can be performed using the state fuel tax rates in the appendix to identify any possible discrepancies.)

\footnotetext{
${ }^{13}$ The ZEV mandate does allow for full to partial credit for plug-in electric and hydrogen-fueled combustion engines, which are classified as transitional zero emission vehicles.
} 
Table 2. Energy Content, Gasoline Gallon Equivalence, and Federal Excise Tax Rates for Motor Fuels $^{14}$

\begin{tabular}{l|c|c|c|c}
\hline \multicolumn{1}{c|}{ Fuel Type } & BTU/Gallon & $\begin{array}{c}\text { Gasoline } \\
\text { Gallon } \\
\text { Equivalent }\end{array}$ & $\begin{array}{c}\text { Current Federal } \\
\text { Tax Rate } \\
\text { (cents/gallon) }\end{array}$ & $\begin{array}{c}\text { Current Federal Tax } \\
\text { Rate (cents/100,000 } \\
\text { BTU }{ }^{16} \text { ) }\end{array}$ \\
\hline Gasoline (regular) & $114,100^{17}$ & 1 gallon & 18.4 & 16.0 \\
\hline No. 2 Diesel & 128,700 & 1.13 gallons & 24.4 & 18.9 \\
\hline Biodiesel (B100) & 117,100 & 1.03 gallons & 24.4 & 20.7 \\
\hline Biodiesel (B20) & 126,380 & 1.11 gallons & 24.4 & 19.2 \\
\hline $\begin{array}{l}\text { Compressed Natural } \\
\text { Gas (CNG) }\end{array}$ & 114,100 & $\begin{array}{c}126.67 \mathrm{cu} . \\
\text { ft./5.66 lbs. }\end{array}$ & 18.3 & 32.5 \\
\hline $\begin{array}{l}\text { Liquefied Natural } \\
\text { Gas (LNG) }\end{array}$ & 74,700 & 0.65 gallons & 24.3 & 21.9 \\
\hline Propane (LPG) & 83,500 & 0.73 gallons & 18.3 & 22.4 \\
\hline Ethanol (E85) & 81,600 & 0.72 gallons & 18.4 & \\
\hline
\end{tabular}

Source: Energy Content taken from Davis, Diegel, and Boundy 2014 and BTU-based fuel tax rates derived from US IRS 2015.

\footnotetext{
${ }^{14}$ Fuels listed represent common commercially available fuels with an established energy-content equivalency and set federal tax rate. Other fuels, such as those referenced in Table 1 are not as common for over the road transportation, such as kerosene, or are not commercially available, such as hydrogen.

${ }^{15}$ With the exception of gasoline and CNG, these energy density factors are all derived from Table B4 in the Transportation Energy Data Book, $32^{\text {nd }}$ Edition. The energy density of B20 was calculated as a weighted average of the energy content of No. 2 diesel fuel and B100. It should be noted that in practice, there will be variation in the energy content of these fuels based on geography, season, and markets.

${ }^{16}$ This rate excludes the $\$ 0.001$ tax for underground storage tank remediation for applicable fuels.

${ }^{17}$ In practice, there is wide variation in the energy content of a gallon of gasoline. While there is no federal statutory definition of the energy content of a gallon of gasoline, the IRS equates a GGE of compressed natural gas as being $126.67 \mathrm{cu}$. ft. This figure is adopted from the National Institute of Standards and Technology Handbook of Weights and Measures (2012), which equates a GGE to $5.660 \mathrm{lbs}$ of natural gas, which is based on the energy content of Indolene of 114,132 BTU. For comparisons sake, the Transportation Energy Data Book cites an energy content of 115,400 for "conventional gasoline" and 112,400 for E10.

${ }^{18}$ E85 is a marketing term and may range in ethanol content from $51 \%$ to $83 \%$ ethanol. The energy equivalent is nearly directly proportional to the ethanol content.
} 


\subsubsection{Weights and Measures for Non-Liquid Fuels}

The values in Table 2 provide for a relative benchmark of the energy content of various fuels, but in practice a wide variety of definitions and measures are implemented in state and federal rules. This makes it particularly difficult to consistently levy fuel taxes on gaseous fuels or electricity used to power a vehicle, which do not naturally exist in a defined volume.

For example, at the federal level, a different baseline is used to compare CNG and electricity to the energy content of gasoline. The IRS defines a gasoline gallon equivalent of $\mathrm{CNG}$ as being 126.67 cubic feet of natural gas, which equates to 114,100 Btu. However, a 2000 rulemaking by the U.S. Department of Energy set the gasoline equivalence of a kilowatt-hour of electricity at $115,000 \mathrm{Btu}$. While the practical difference is most likely negligible to the consumer, the aggregate impact of this discrepancy could have a substantive effect on revenues and further complicates enforcement and parity of fuel taxes.

It is important to note that in reality, there is no single, definitive energy-content value for a gallon of gasoline, because energy content depends on a multitude of factors that vary both absolutely and proportionally based on season, geography, regulation, and economics. ${ }^{19}$ Without a single energy-content value, it becomes problematic to establish an accurate baseline against which to judge other fuels, particularly when there is not a volumetric equivalent measure, such as when comparing gasoline to compressed natural gas or electricity. Often at this point, weights and measures standards are used to define a commonly accepted unit.

\subsubsection{Electrification of Transportation and the Emergence of Home Fueling}

\subsubsection{Electrification of Transportation}

Electricity is a regulated product in most states. It has its primary use in sectors other than transportation, and it does not fall under the purview of federal motor fuel taxes (or state motor fuel taxes for that matter, although some have instituted fees, which will be discussed later). While plug-in and hybrid vehicles currently represent a small portion of overall registrations, their market presence is expected to increase in the coming years as additional models come to market, prices decrease, fuel efficiency standards ratchet up, and emissions regulations become more stringent. Figure 13 shows the cumulative sales of light-duty PEVs from January 2010 to June 2015. PEVs present an entirely new set of challenges to the solvency of the Highway Trust Fund and will be discussed in more detail in Section 4.

\footnotetext{
${ }^{19}$ The lack of a single, consistent energy-content factor is not exclusive to gasoline and holds true for other fuels. In many cases, there are regulations that allow for a range.
} 


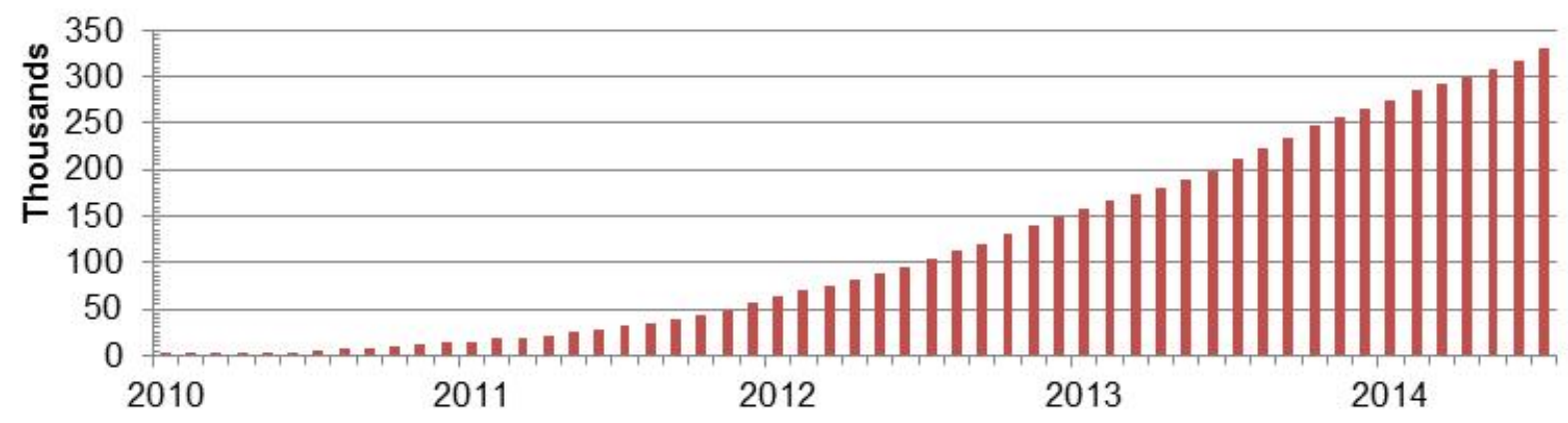

Figure 13. Cumulative plug-in electric vehicle sales. Source: Inside EVs 2015.

\subsubsection{Emergence of Home Charging and Fueling}

Vehicles that are capable of refueling or charging from home, such as PEVs or compressed natural gas vehicles, bypass traditional modes of delivering, selling, and taxing fuel and create additional enforcement challenges. For PEVs in particular, addressing this is not a trivial challenge because they can be charged in a variety of location without additional equipment.

In cases where only household voltage is being used (110V or Level 1 charging), many of the outlets also could be used for purposes other than charging a vehicle. Data that stems from the U.S. Department of Energy's EV Project ${ }^{20}$ shows that $82 \%$ of vehicle charging occurs at the home (Smart and Schey 2012). The challenge then quickly becomes distinguishing the electricity that powers a vehicle from that used for another purpose, such as running a household appliance. While there are technologies that may be able to facilitate this differentiation, some may prove to be prohibitively expensive, which could serve as a barrier to vehicle electrification, and/or be easily circumvented.

Similar to electricity, natural gas vehicles also are able to fuel at home. While the current adoption of natural gas home fueling dispensers is somewhat limited, several major companies have signaled their interest and intent to significantly lower the cost of home fueling from natural gas, which could increase demand for natural gas home fueling (Lefebvre and Bennett 2012). The need to collect motor fuel taxes from CNG vehicles that refuel at home will increase commensurately with this demand. A CNG vehicle that fuels at home may also choose to fuel at retail locations, where they may be charged a motor fuel tax, which creates a situation where some portion of fuel being used would be subject to tax while some would not.

\footnotetext{
${ }^{20}$ The EV Projects was launched by the U.S. Department of Energy, ECOtality, Nissan, General Motors, and Idaho National Laboratory in 2009 to deploy and collect data on the use of electric vehicles and chargers
} 


\section{Alternative Approaches to Volumetric Motor Fuel Excise Taxes}

Given all of the previously outlined complications to collecting motor fuel taxes for electricity and alternative fuels, a number of states have tried to address these by modifying or supplementing the current approach of taxing fuels based on volume. There are numerous ways to do so, yet no single best practice has seemingly emerged or been adopted. This paper highlights two of the more common approaches being pursued at the state level - energy-content based taxation and annual vehicle fees - and outlines implementation considerations. These considerations are provided in the context of establishing greater parity among fuels in how they pay motor fuel excise taxes.

\subsection{Energy-Content Based Taxation}

Following the assumption that energy content (BTUs) more closely correlates with the impact that a vehicle has on the road than fuel usage (gallons) does, and given the disparity of energy density among conventional and alternative fuels, many states are exploring or have already implemented legislation that bases fuel taxation levels on a fuel's energy content. ${ }^{21}$ The impact of adjusting tax rates to account for energy content ranges from subtle (as in the case of B20) to substantial (as in the case of liquefied natural gas), as Table 3 illustrates. Variation in these rates can have substantial financial impact on vehicle operations, particularly for larger vehicles that use relatively large quantities of fuel.

Specifically, Table 3 shows a number of alternative fuels and their average energy content per gallon equivalent, with the energy equivalence also expressed in terms of gasoline gallon equivalents. The next two columns outline the current federal motor fuel tax rate and what that rate would be based on a per energy unit basis. The final two columns demonstrate how those fuel tax rates would be adjusted to have an energy equivalency of gasoline or diesel. Both values are provided as a number of alternative fuels can be a substitute for gasoline or diesel depending on the application.

\footnotetext{
${ }^{21}$ In August 2015, the President signed HR 3236, which among other things assesses the federal fuel tax levied against LNG on a BTU basis relative to diesel fuel.
} 
Table 3. Energy-Content Based (ECB) Motor Fuel Excise Tax Rates Relative to the Energy Content of Gasoline and Diesel Fuel ${ }^{22}$

\begin{tabular}{|c|c|c|c|c|c|c|}
\hline Fuel Type & $\begin{array}{c}\text { BTU/ } \\
\text { Gallon }\end{array}$ & $\begin{array}{c}\text { Gasoline } \\
\text { Gallon } \\
\text { Equivalent }\end{array}$ & $\begin{array}{c}\text { Current Tax } \\
\text { Rate } \\
\text { (cents/gallon) }\end{array}$ & $\begin{array}{c}\text { Current } \\
\text { Tax Rate } \\
\text { (cents/ } \\
100,000 \\
\text { BTU) }\end{array}$ & $\begin{array}{l}\text { ECB Rate, } \\
\text { Indexed to } \\
\text { Gasoline Tax } \\
\text { (cents/gallon) }\end{array}$ & $\begin{array}{l}\text { ECB Rate, } \\
\text { Indexed to } \\
\text { Diesel Tax } \\
\text { (cents/gallon) }\end{array}$ \\
\hline $\begin{array}{l}\text { Gasoline } \\
\text { (regular) }\end{array}$ & 114,100 & 1 gallon & 18.4 & 16.0 & 18.4 & 21.6 \\
\hline No. 2 Diesel & 128,700 & 1.13 gallons & 24.4 & 18.9 & 20.7 & 24.4 \\
\hline $\begin{array}{l}\text { Biodiesel } \\
\text { (B100) }\end{array}$ & 117,100 & 1.03 gallons & 24.4 & 20.7 & 18.9 & 0.1 \\
\hline $\begin{array}{l}\text { Biodiesel } \\
\text { (B20) }\end{array}$ & 126,380 & 1.11 gallons & 24.4 & 19.2 & 20.4 & 23.9 \\
\hline $\begin{array}{l}\text { Compressed } \\
\text { Natural Gas } \\
\text { (CNG) }\end{array}$ & 114,100 & $\begin{array}{l}126.67 \mathrm{cu} . \\
\text { ft./5.66 lbs. }\end{array}$ & 18.3 & 16.0 & 0.1 & 0.2 \\
\hline $\begin{array}{l}\text { Liquid } \\
\text { Natural Gas } \\
\text { (LNG) }\end{array}$ & 74,700 & 0.65 gallons & 24.3 & 32.5 & 12.0 & 14.1 \\
\hline $\begin{array}{l}\text { Propane } \\
\text { (LPG) }\end{array}$ & 83,500 & 0.73 gallons & 18.3 & 21.9 & 13.4 & 15.7 \\
\hline Ethanol (E85) & 81,600 & 0.72 gallons & 18.4 & 22.4 & 13.2 & 15.5 \\
\hline
\end{tabular}

${ }^{22}$ All footnotes from Table 2 also apply to Table 3. 


\subsubsection{Considerations for Implementation of Energy-Content Based Taxation}

\subsubsection{Establishing a Baseline for Energy Content}

One intrinsic challenge in the implementation of an energy-content based fuel tax is that gasoline and diesel motor fuel tax rates are themselves not set at a rate of relative energy equivalence. At the federal level, gasoline users pay about 19\% less per BTU in fuel taxes than diesel fuel users pay. The implication is that implementing a tax scheme that treats all fuels equally on an energycontent basis may require an overhaul of all fuel taxes, which could have significant impacts on overall fuel tax revenues.

A second option of implementation would be to index the energy-content rates of alternative fuels to either gasoline or diesel fuel, based on which of the two fuels an alternative fuel is most likely to displace. This is admittedly a somewhat arbitrary assignment, given the ability of some fuels, such as CNG, to serve as substitutes for both gasoline and diesel, but it does present a path forward for implementation. Table 3 provides samples of what energy-content based rates would look like if based on current gasoline tax rates or on current diesel tax rates. In both cases, the definition of a gasoline gallon equivalent or a diesel gallon equivalent is critical to ensuring that fuels are taxed on an energy basis and that there is parity across traditional and alternative fuels.

\subsubsection{Overall Funding Impact}

Table 3 indicates that most alternative fuel tax rates would decrease from current levels under energy-content based taxation when indexed to either gasoline or diesel rates, so it is a fair expectation that overall revenue from fuel taxes would also decrease in the near term. The extent of this decrease will depend on the relative adoption of each fuel and the pace at which any change in rates are implemented. However, because the use of alternative fuels is currently small compared to gasoline and diesel fuel consumption, the expected effect would be minimal in the near future. If the energy-content based taxation is replacing an existing state decal program (which is discussed in more detail later), the impact to funding would in many cases be a net positive to highway funding. However, there would be a corollary negative impact on users of alternative fuels.

One approach that some states have taken is to phase in energy-content based taxes over time to allow for the impact to both consumers and transportation agencies to be absorbed gradually. In this scenario, a timeline would be selected, and excise tax rates would change from current levels at set intervals.

\subsubsection{Blending and Conversion}

Energy-content based taxation for biofuels proves to be particularly challenging given the extent to which biofuels are embedded into gasoline blends. Biofuels, in the form of ethanol, are blended into nearly every gallon of gasoline (most often at proportions of up to $10 \%$, or E10) ${ }^{23}$ for properties as a fuel and in larger quantities in fuels such as E85.

\footnotetext{
${ }^{23}$ Current EPA regulations allow for ethanol blends of up to $15 \%$ (E15) to be used in conventional vehicles of Model Year 2001 and newer, but there are currently limited retail outlets where E15 is available.
} 
Ethanol can be blended with gasoline at any point in the supply chain from the refinery to the fuel dispenser, as shown earlier in Figure 7. Levying an energy-content based fuel tax at any one point in the supply chain does not guarantee that the ethanol blend being taxed at that point, will be the same one that ends up being sold to vehicles. Because of the flexibility in blending biofuels, and the fact that it can occur across multiple states/jurisdictions, taxing biofuel/ethanol blends can create opportunities for arbitrage and tax avoidance.

Ethanol content in gasoline also varies regionally and seasonally as refiners adjust blends to account for regulatory requirements, seasonal temperature changes, and market fluctuations for the various feedstock components in gasoline. It would be extremely complex to develop an adaptive scale for the energy content for various ethanol blends, particularly when considering mechanisms for monitoring and metering to enforce motor fuel taxes. A possible solution that could perhaps address this issue would require moving the point of taxation to the retail level in order to allow for a more accurate accounting of the fuel sold to consumers. However, even in this case, policymakers would have to determine how to tax lower-level blends of ethanol that are marketed as gasoline, such as E10 or E15. Fuel retailers may also view the accounting involved in compliance as an unnecessary burden and liability.

While E10 and E15 are taxed at the federal level and in most states as gasoline, a number of states have set a separate tax rate for E85, a fuel that is typically marketed separately from other ethanol blends. However, the ethanol content of E85 can vary from 51\% to 83\% (DOE 2014), precluding an accurate, fixed rate from reflecting the energy content of a given gallon of the fuel. Another possible solution at the federal level is to use renewable identification numbers (RINs) as a proxy for ethanol content.

\subsubsection{Plug-In Electric Vehicles and Home Fueling}

Readers might have noticed that an energy-content conversion rate for electricity is missing from Table 3. This is because electricity is not defined as a motor fuel in federal statute nor in many states. However, a correlation can be drawn between the energy content in a gallon of gasoline or diesel fuel and that of a kilowatt-hour of electricity to provide for an energy-content based comparison. Table 4 shows what a gasoline and diesel gallon equivalent rate per kilowatt-hour would be using 114,100 and 128,700 BTU, respectively, as a baseline for these fuels. ${ }^{24}$

Table 4. Electricity Energy Equivalence to Gasoline and Diesel

\begin{tabular}{l|c|c|c|c|c}
\hline & BTU/kWh & $\begin{array}{c}\text { Gasoline } \\
\text { Gallon } \\
\text { Equivalent } \\
\text { (kWh) }\end{array}$ & $\begin{array}{c}\text { GGE Tax } \\
\text { Rate per } \\
\text { kWh }\end{array}$ & $\begin{array}{c}\text { Diesel Gallon } \\
\text { Equivalent (kWh) }\end{array}$ & $\begin{array}{c}\text { DGE Tax } \\
\text { Rate (cents/ } \\
\text { kWh) }\end{array}$ \\
\hline Electricity & 3412.14 & 33.44 & $\$ 0.0055$ & 37.72 & $\$ 0.0073$ \\
\hline
\end{tabular}

As noted above, a key challenge of levying an excise tax on electricity is the absence of a point of enforcement under current taxation policies. Policymakers would have to determine mechanisms for accurate metering and reporting of electricity used for transportation purposes. Some options include installing separate meters to track electricity going only to an EV charger

\footnotetext{
${ }^{24}$ Notably, the federal equivalency for 1 GGE of electricity is defined as 115,000 BTU. 114,000 BTU is used in this case to provide consistency in the analysis among fuels.
} 
or a smart charger that would report the amount of electricity sent to a vehicle. However, both of these options would impose hardware and installation costs that are not required for other alternative fuels. The installation of a separate meter for an electric or natural gas vehicle is another option, but this comes at a potentially significant cost to either the consumer, business, or utility. In addition to the capital cost, a number of utilities charge a monthly fee for the monitoring and billing associated with providing service to each meter. If a meter was installed and used to recover motor fuel taxes, gas and electric utilities would inherently serve some role in collecting these taxes, which may be perceived as a burden and would be subject to additional regulatory processes in many cases.

When considering both of these options, it's important to note that a number of states and local governments already charge a sales tax on electricity that is likely not (directly) levied on existing motor fuels and also is not used exclusively for supporting transportation infrastructure. Untangling motor fuel and sales taxes in a way that fairly and efficiently redirects revenue presents an additional set of challenges to revenue-collecting agencies.

\subsection{Vehicle Fees and Decals}

Several states have implemented flat or tiered fees to generate revenues for transportation infrastructure. Motivations to do so vary from encouraging the purchase of more fuel efficient vehicles, incentivizing the use of one or more alternative fuels, and/or recovering motor fuel taxes not collected on vehicles that are not subject to motor fuel taxes or fuel from home. ${ }^{25}$ These programs are often administered via a fee paid at the time of the annual registration or inspection of a vehicle and/or by requiring the purchase of a decal to be displayed on the vehicle. ${ }^{26}$ At the time of this report, 10 states have decals that serve in the place of motor fuel taxes for vehicles using $\mathrm{CNG}$, liquefied natural gas (LNG), and/or propane (liquefied petroleum gas, or LPG) as shown below in Figure 14. Recent legislative trends point to decals being phased out for CNG, LNG, and LPG, but being added for PEVs.

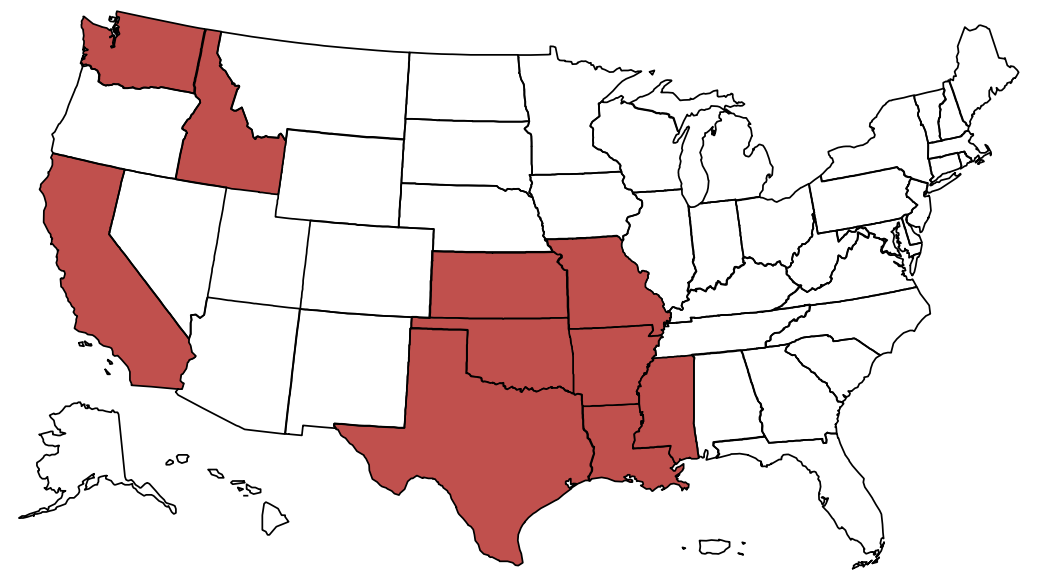

Figure 14. States with an annual fee of decal for CNG, LNG, and/or LPG

\footnotetext{
${ }^{25}$ This section examines fees as a state policy and assumes that action will only be taken at the state level since states maintain responsibility for vehicle registration. However, the same basic conclusions and challenges would apply to a federal fee.

${ }^{26}$ In addition to proving compliance with applicable laws, these decals can also be used a means to communicate additional information about the vehicle to first responders.
} 


\subsubsection{Considerations for Implementation}

Implementation of vehicle fees and decals merits careful consideration of fairness among transportation system users and efforts to promote the deployment of alternative fuels and advanced vehicles.

\subsubsection{Fair and Efficient Taxation}

An important step in setting up a fee or decal system is to determine the amount(s) and structure of the fee. While a fee or decal may help to recover revenue that's otherwise uncollected or serve to incentivize certain fuel/vehicle technologies, there will always be a set of participants who benefit more than others unless the fee directly relates to usage. In many cases, if the fee is based on a technology or fuel type, those who drive more will be paying less on a per mile basis. Table 5 shows a hypothetical situation with a $\$ 100$ annual registration fee and the effective rate paid by several classes of vehicles using values for typical annual mileage.

Table 5. Relative Per-Gallon Cost for Various Vehicle Classes with $\$ 100$ Annual Decal/Registration Fee

\begin{tabular}{|c|c|c|c|c|c|}
\hline $\begin{array}{l}\text { Vehicle } \\
\text { Type }\end{array}$ & $\begin{array}{l}\text { Annual } \\
\text { Fuel Use } \\
\text { (GGE) }^{27}\end{array}$ & $\begin{array}{c}\text { Per- } \\
\text { Gallon } \\
\text { Cost with } \\
\text { \$100 Decal }\end{array}$ & $\begin{array}{c}\text { Revenue Lost } \\
\text { Relative to } \\
\text { Diesel Tax (at } \\
\$ 0.244)\end{array}$ & $\begin{array}{l}\text { Revenue Lost } \\
\text { Relative to } \\
\text { Gasoline Tax } \\
\text { (at \$0.184) }\end{array}$ & $\begin{array}{c}\text { Decal/Fee } \\
\text { Needed to } \\
\text { Recover Lost } \\
\text { Revenue }\end{array}$ \\
\hline $\begin{array}{l}\text { Class } 8 \\
\text { Truck }\end{array}$ & 12,889 & $\$ 0.008$ & $\$ 2,271.58$ & & $\$ 2,371.58$ \\
\hline Transit Bus & 10,440 & $\$ 0.010$ & $\$ 1,820.96$ & & $\$ 1,920.96$ \\
\hline $\begin{array}{l}\text { Refuse } \\
\text { Truck }\end{array}$ & 9,877 & $\$ 0.010$ & $\$ 1,717.37$ & & $\$ 1,817.37$ \\
\hline $\begin{array}{l}\text { Para. } \\
\text { Shuttle }\end{array}$ & 3,065 & $\$ 0.033$ & $\$ 463.96$ & & $\$ 563.96$ \\
\hline Taxi & 2,813 & $\$ 0.036$ & $\$ 417.59$ & & $\$ 517.59$ \\
\hline $\begin{array}{l}\text { Delivery } \\
\text { Truck }\end{array}$ & 1,974 & $\$ 0.051$ & $\$ 263.22$ & & $\$ 363.22$ \\
\hline School Bus & 1,896 & $\$ 0.053$ & $\$ 248.86$ & & $\$ 348.86$ \\
\hline Police & 1,423 & $\$ 0.070$ & & $\$ 161.83$ & $\$ 261.83$ \\
\hline Light Truck & 683 & $\$ 0.146$ & & $\$ 25.67$ & $\$ 125.67$ \\
\hline $\begin{array}{l}\text { Light-Duty } \\
\text { Car }\end{array}$ & 524 & $\$ 0.191$ & & $(\$ 3.58)$ & $\$ 96.42$ \\
\hline
\end{tabular}

The table clearly shows that for larger vehicles, which use more fuel annually, the effective tax rate would be much less than for consumer cars and trucks in this scenario. In the case of an average light-duty vehicle, a $\$ 100$ annual fee would actually amount to slightly more than one year's worth of a gasoline tax of $\$ 0.184$ /gallon. To begin to address this discrepancy, some states have set decal fee levels based upon vehicle classes and weights.

\footnotetext{
${ }^{27}$ Average mileage values are derived from FHWA 2013b and the American Public Transit Association's Public Transportation Fact Book (2014).
} 


\subsubsection{Inconsistent Taxation in Commercial Transactions}

Enforcement of a decal program can prove challenging in retail fueling stations, where a combination of vehicles with and without the decal will often make transactions. Vehicles registered out of state may not have a decal (or at least a valid decal) and in many cases will be required to pay the fuel tax. For commercial carriers that pay fees through IFTA, this can be particularly problematic, as they will always pay the out-of-state rate, which puts interstate freight carriers at a relative disadvantage if they are also required to purchase a decal.

These scenarios inherently raise questions about whose responsibility it is to distinguish between a vehicle that has a decal and one that does not, and ultimately who is liable for the collection of fuel taxes. Even if properly enforced, in-state and out-of-state customers will pay different tax levels for the same product, which may raise additional legal concerns. In ATA v. Scheiner (1986), the U.S. Supreme Court ruled that several fees instituted by the state of Pennsylvania discriminated against out-of-state carriers and violated the Commerce Clause of the U.S. Constitution.

Because motor fuel taxes are often not itemized on receipts, it is also a possibility that a vehicle owner may purchase a decal, but also be subject to pay motor fuel tax. The likelihood of this happening increases at unoccupied fueling stations, which would not necessarily be able to verify whether a vehicle has a decal. For this reason and others, some of these stations limit access to pre-approved vehicles by issuing fuel cards, which in turn can limit public access to alternative fuel stations.

Finally, some states or localities require fueling stations to post the highest possible price on their signage. In states with decals, the price on the sign would include fuel taxes, unless specified otherwise, and would require third-party verification of a decal. This not only creates the possibility of double taxation, but also presents marketing challenges for retail alternative fuel providers. Stations would have to post a higher price than that charged to consumers with a decal, who coincidentally would likely comprise a large majority of fuel users in a state with a decal program.

\subsubsection{Parity in Fees Levied Against Electric Vehicles}

In general, the number of state decal or fee programs is declining for CNG, LNG, and LPG, but the relatively recent availability of PEVs has led many decision makers back to this mechanism as a way to recoup lost motor fuel taxes from electric vehicle drivers as shown in Figure 15. Establishing an appropriate fee, however, is not as straightforward as it might seem and can have some unintended consequences if the fee is not carefully considered. 


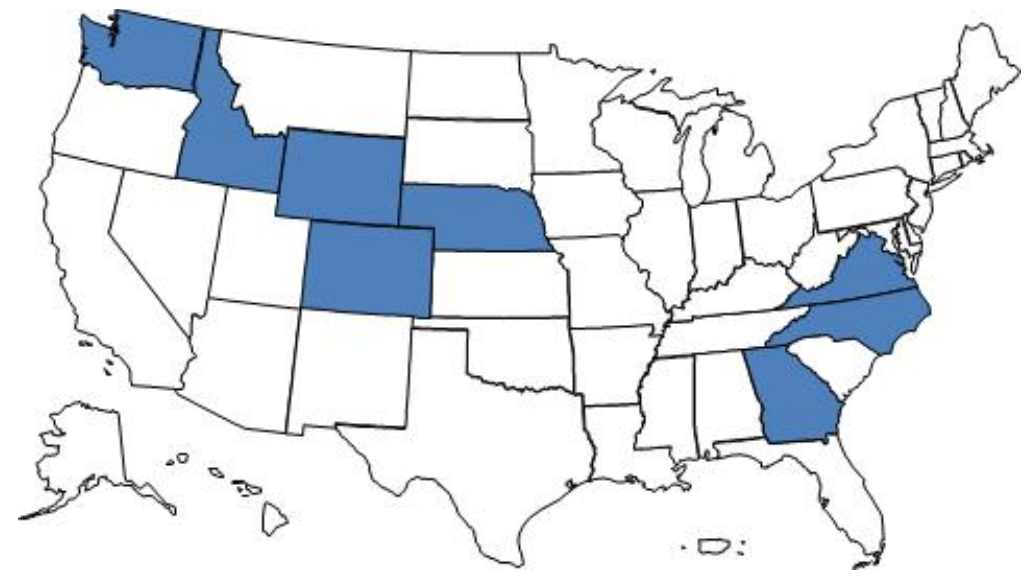

Figure 15. States with an annual fee on electric vehicles

There are multiple types of vehicles that use electricity for some level of propulsion. Hybridelectric vehicles (HEVs) generate electricity on-board to power an electric motor that supplements a gasoline engine; these vehicles cannot plug into the grid and all energy used can be attributed to gasoline. Plug-in hybrid electric vehicles (PHEVs) utilize electricity from the power grid, but can also run on gasoline. All-electric vehicles (EVs) rely solely on electricity from the grid and contain no internal combustion engine. The distinction is very important, as HEV drivers pay motor fuel taxes on all of the energy the vehicle uses, while EV drivers pay no motor fuel taxes on the energy the vehicle uses. PHEV drivers can occupy either extreme, utilizing either entirely electricity or entirely gasoline throughout the life of the vehicle, although the reality is more likely to exist somewhere in between.

PEVs (meaning both EVs and PHEVs) convert roughly $60 \%$ of the energy they draw from the electric grid into kinetic energy that is used for propulsion (Chae et al. 2011; Gautam et al. 2011; Miller et al. 2011). Conventional gasoline vehicles, on the other hand, convert only about $17 \%$ to $21 \%$ of the energy stored in gasoline to power that is available at the wheels (fueleconomy.gov 2013). PEVs' higher efficiency led the U.S. Environmental Protection Agency to develop a miles-per-gallon-equivalence (MPGe) for electric vehicles, which measures vehicle mileage per unit of energy.

Table 6 shows the federal fuel taxes that an average new vehicle with an internal combustion engine (ICE) would pay in a year compared against an EV and a PHEV on an MPGe basis. The PHEV has been assigned a utility factor of $60 \%$ based on an electric range of 38 miles, which is the stated range for a 2014 Chevrolet Volt (SAE 2010). The utility factor indicates the average percentage of miles traveled by a PHEV that is powered by electricity as calculated by the Society of Automotive Engineers. 
Table 6. Estimate of Annual Federal Fuel Taxes Paid by an Average Conventional Vehicle, Nissan Leaf EV, and Chevrolet Volt PHEV if Electricity Were Taxed as a Motor Fuel

\begin{tabular}{ll|crr|r}
\hline $\begin{array}{l}\text { Vehicle } \\
\text { Type }\end{array}$ & $\begin{array}{l}\text { Vehicle Make and } \\
\text { Model }\end{array}$ & \multirow{2}{*}{ MPGe $^{28}$} & $\begin{array}{r}\text { Annual } \\
\text { Mileage }\end{array}$ & $\begin{array}{r}\text { Utility } \\
\text { Factor }\end{array}$ & \multicolumn{2}{c}{$\begin{array}{l}\text { Estimated Annual } \\
\text { Gas Tax }\end{array}$} \\
\hline ICE & Average New Car & 25.4 & 13,310 & N/A & $\$ 96.42$ \\
\hline EV & Nissan Leaf & 99 & 13,310 & 1.0 & $\mathbf{\$ 2 4 . 7 4}$ \\
\hline PHEV & Chevrolet Volt Total & & 13,310 & N/A & $\$ \mathbf{4 2 . 2 8}$ \\
\hline & Chevrolet Volt Electricity & 93 & 7,986 & 0.6 & $\$ 15.80$ \\
\hline & Chevrolet Volt Gasoline & 37 & 5,324 & 0.4 & $\$ 26.48$ \\
\hline
\end{tabular}

The table illustrates the difficulty in developing a single fee for PEVs that would displace lost revenue from motor fuel taxes and also the impact of increased efficiency on annual fuel tax revenues. A fee of approximately $\$ 96$ would be needed to fully recover federal fuel tax revenue that would be collected from the average new vehicle. This value, however, ignores both the efficiency gain of PEVs and the fuel taxes that may already be paid by a PHEV driver. Based on the data in Table 6, during the course of one year, the Nissan Leaf EV would effectively displace $\$ 24.74$ in motor fuel tax revenue on an MPGe basis under the current system of taxation. This is $26 \%$ of what would be generated by a typical new conventional vehicle, which is reflective of the greater efficiency of the Leaf $(4 \mathrm{x})$ in converting energy to vehicle miles. A conclusion of this analysis might be that about $\$ 25$ would be an equitable fee for an EV. However, Table 6 shows that this would effectively penalize the owner of a Chevrolet Volt PHEV. The average Chevrolet Volt owner would already be paying around $\$ 26$ in fuel taxes because the vehicle runs on gasoline for $40 \%$ of its miles. The amount of fuel taxes displaced by its electric motor is closer to $\$ 16$ per year. In actuality, annual fees adopted by states range from $\$ 50$ to $\$ 300$.

An alternative approach to a flat fee could be to index the registration fee for a PEV according to vehicle battery capacity. This assumes the size of the battery to be a reasonable proxy for the utility factor of a given vehicle, which correlates to the amount of electric-drive miles a vehicle travels. Working backwards from Table 6, this would create a fee that would be slightly less than $\$ 1$ per $\mathrm{kWh}$, as shown in Table 7.

Table 7. Approximate Fuel Tax for a Nissan Leaf and Chevrolet Volt in the Context of Their Battery Capacities

\begin{tabular}{l|c|c|c}
\hline $\begin{array}{c}\text { Vehicle Make } \\
\text { and Model }\end{array}$ & $\begin{array}{c}\text { Battery } \\
\text { Size (kWh) }\end{array}$ & $\begin{array}{c}\text { Displaced Revenue from Electric } \\
\text { Drive Miles }\end{array}$ & $\begin{array}{c}\text { Displaced Revenue per } \\
\text { kWh }\end{array}$ \\
\hline Chevrolet Volt & 16 & $\$ 15.19$ & $\$ 0.95$ \\
\hline Nissan Leaf & 24 & $\$ 22.30$ & $\$ 0.93$ \\
\hline
\end{tabular}

A drawback to this approach is that, without a cap on battery size, a battery-capacity based fee would handicap EVs with large capacities, such as the Tesla Model S, which has a 60kWh battery in its base model. This would, in turn, serve as a penalty for EVs that have extended driving ranges. Furthermore, PEVs use various control strategies to manage their battery packs, which can create discrepancies between battery size and vehicle range.

\footnotetext{
${ }^{28}$ Average new car fuel economy from MPGe for Nissan Leaf and Chevrolet Volt from U.S. Environmental Protection Agency Fuel Economy Guide. Average new car fuel economy from UMTRI (2015).

${ }^{29}$ Average annual vehicle mileage assumed to be 12,000 miles.
} 


\subsubsection{Enforcement of a Decal Program}

A final challenge comes with the difficulty of identifying vehicles that qualify for a decal or registration fee. Enforcement in a number of states is based on DMV records, and there is not always a way to connect a vehicle to a particular fuel or propulsion technology. Vehicle identification numbers (VINs) do not always identify how a vehicle is fueled, nor do they necessarily distinguish between the various levels of vehicle electrification. Additionally, several automobile manufacturers produce vehicles that are capable of being "upfitted" to use an alternative fuel, but may or may not ultimately be converted. This can occur with CNG or LPG vehicles in particular, for which auto manufacturers produce vehicles that have been modified to accommodate these fuels, but the actual alternative fueling system is installed by a third party. In these cases, a determination of whether a vehicle has been converted to use an alternative fuel is nearly impossible without visual inspection. Furthermore, state DMVs may not be able to identify vehicles that have been converted to run on alternative fuels without a working knowledge of alternative fuel vehicles and systems. 


\section{Alternative Approaches to Motor Fuel Excise Taxes}

While registration fees and energy-content based taxation are common ways of adapting the current motor fuel excise tax system to alternative fuels and advanced vehicle technologies, some governments are exploring broader overhauls of the way in which users of transportation infrastructure pay for its upkeep and expansion where others have sought to have third-parties manage and maintain roads (an issue not discussed in this paper). The following provides an overview of programs that are being explored or have been implemented at the state and provincial level that substitute for motor fuel taxes.

\subsection{Mileage-Based User Fees}

Rather than charging per gallon of fuel, some states have proposed charging a tax based on vehicle miles traveled (VMT), similar to the way in which a number of toll lanes currently operate in various part of the country: A fee is paid based upon a number of factors such as miles driven on a given stretch of road and number of vehicle axels. A mileage-based user program decouples vehicle fuel efficiency and infrastructure funding. And depending on how the program is structured, a mileage-based program could also set rates for various vehicle classes so that they are aligned with their relative impact on the road. This decoupling would remove a current incentive for vehicle fuel efficiency, which the current motor fuel tax amplifies through fuel savings, and would replace it with an incentive for driving less. Mileage-based user fees allow for fuel and technology parity and also provide an opportunity to recover revenue lost from PEVs and any other vehicles that fuel at residences. Enforcement, privacy, and data collection are concerns that have been expressed with mileage-based programs. Similar to the gas tax, the mileage tax would need to consider inflation, as it is still a usage-based tax that could potentially require legislative approval to adjust.

The state of Oregon recently codified a mileage-based user fee pilot into a statewide, voluntary program for VMT charging through legislation passed in 2013 with the program to begin July 1, 2015. The program allows for up to 5,000 drivers of certain types of light-duty vehicles (under $10,000 \mathrm{lbs}$.) to participate in a program that will pay $\$ 0.015 / \mathrm{mile}$ in lieu of the $\$ 0.30 /$ gallon state gasoline tax (Road Usage Charge Program [RUCP] Fact Sheet 2013). Burden of proof for miles traveled outside of the state of Oregon lies with the driver, as the program does not mandate the use of GPS.

\subsection{Sales Tax on Fuel Consumption}

Another alternative to the gasoline tax is replacement of a flat per-gallon rate with a variable-rate tax. ${ }^{30}$ Doing so would allow revenues to keep pace with inflation and relieve some of the pressure created by increased road construction and maintenance costs (however, road construction costs do not always follow inflation). Such a tax also avoids the need to refer fuel tax increases to a vote. A sales tax on gasoline and diesel fuel would not resolve the tension between fuel efficiency and infrastructure funding.

However, a sales tax would also be tied to volatile motor fuel and petroleum markets, which could make revenue forecasting difficult. It could also create a disconnect between fuel tax

\footnotetext{
${ }^{30}$ Some states already charge a sales tax on fuel purchases. However, this is in addition to existing excise taxes. The strategy outlined here would propose a wholesale replacement of existing excise taxes with a sales tax.
} 
revenues and inflation in construction markets. Some have proposed avoiding this by indexing the current per-gallon tax to economy-wide inflation instead of fuel sales, which would present an alternative to a pure sales tax (Madowitz and Novan 2013).

It is not clear whether a sales tax would be effective in taxing alternative fuels and electricity, some of which already have sales taxes levied against them as they are primarily used for nontransportation purposes. This would raise some of the same enforcement issues discussed earlier related to distinguishing between end uses and allocating funds accordingly. It is conceivable that a sales tax on motor fuels would eliminate the need for dedicated infrastructure funding and rely instead on general fund revenues, which would have both advantages and drawbacks.

The Commonwealth of Virginia eliminated its $\$ 0.175 /$ gallon motor fuels tax in favor of a 3.5\% sales tax on gasoline and a $6 \%$ sales tax on diesel fuel. ${ }^{31}$ The state subjects electric vehicles to a $\$ 64$ registration fee in addition to any sales tax they pay for gasoline (in the case of PHEVs). ${ }^{32}$ The sales tax is expected to generate an additional $\$ 3.5$ billion in revenue for transportation projects over the next five years relative to what the previous system would have generated. At the federal level, there are only a few precedents for a percentage-based excise tax. ${ }^{33}$

\subsection{Carbon Tax}

In an effort to reduce greenhouse gas emissions, some governments have proposed or are implementing carbon taxes that would be levied against certain products based upon their greenhouse gas emissions. In many cases, motor fuels are heavily affected, as they account for a significant portion of greenhouse gas emissions. While carbon taxes present an opportunity to incentivize less greenhouse-gas-intensive transportation, this objective does not necessarily correlate to generating the revenue needed to maintain the roads.

At a basic level, a carbon tax on motor fuels could be implemented either in lieu of or in addition to motor fuel excise taxes. It could be placed specifically on fuels or imposed economy wide. In any case, the ability to align infrastructure funding with emissions goals depends squarely on whether a carbon tax is static, such as the current motor fuels tax, or dynamic to provide for a more active enforcement of a carbon cap and generate sufficient revenue to keep up with inflation in infrastructure costs. A static carbon tax would eventually have many of the drawbacks that current motor fuel taxes have, possibly amounting to a zero-sum game in terms of funding infrastructure over the long term. Scoping the applicability of a carbon tax would determine whether non-traditional vehicle energy sources (such as electricity) are taxed consistently with other motor fuels. Ultimately, the question of appropriation of revenues from a carbon tax will ultimately determine its viability to address transportation funding shortfalls.

In 2008, the Canadian province of British Columbia instituted a carbon tax in addition to motor fuel taxes. British Columbia's carbon tax is revenue neutral, providing tax reductions elsewhere in proportion to revenues gained through the carbon tax (British Columbia 2013). The carbon tax

\footnotetext{
${ }^{31}$ While the sales tax is a percentage of a sale, the actual tax levied reflects average wholesale prices over a period of six months. The figure is adjusted twice annually.

32 In February 2014, the $\$ 64$ fee was repealed for hybrid vehicles, but remains in place for electric vehicles.

${ }^{33}$ One example of a federal percentage-based tax levied directly on consumers is a $10 \%$ tax on indoor tanning services.
} 
is levied in proportion to equivalent tons of carbon dioxide emitted by a given fuel. ${ }^{34}$ In this specific case, a carbon tax imposed on motor fuels does not contribute either positively or negatively to transportation funding, as it does not generate additional revenue or change existing revenues from motor fuel taxes. However, higher overall taxes on fuel may encourage greater fuel efficiency or less driving, thereby reducing motor fuel tax revenues.

${ }^{34}$ Specific rates can be found at www.sbr.gov.bc.ca/documents_library/bulletins/mft-ct_005.pdf. 


\section{Conclusion and Future Efforts}

Motor fuel taxes, which serve as the primary means of funding our nation's transportation infrastructure, are inextricably linked to the ways in which we fuel our vehicles, the types of fuels that our vehicles use, the distance we drive, and the fuel efficiency of our vehicles. Due to political and inflationary pressures, motor fuel taxes have failed to provide sufficient revenue, while variations in their administration among state and federal jurisdictions have created a mix of incentives and disincentives for alternative fuels and advanced vehicle technologies. This web of complexities and any attempt to untangle it carry substantial implications for our economy, energy security, the quality of the transportation system, and the environment.

Under the current framework, policymakers risk underfunding our infrastructure and transit systems if they incentivize vehicle efficiency or reduced driving miles (and associated reductions in petroleum use and vehicle emissions). While more extensive changes are needed to address these issues, several short-term measures can help to level the playing field for alternative fuels and advanced vehicle technologies while also contributing toward funding infrastructure. Energy-content based taxation has been pursued by a number of states as a way to level the playing field across fuels, whereas fees or decals have been employed to recover uncollected revenues and/or provide incentives.

Energy-content based taxation is a step toward removing the financial penalty on less energydense fuels. Implementation of this policy at the federal level could help to align practices across states by providing a set of standards with which to work from. Organizations such as IFTA can greatly enhance the effectiveness and coordination of such an effort. However, without broader consideration of the mechanisms by which to collect revenue from drivers of vehicles that are powered by electricity or drop-in fuels such as ethanol, the overall effectiveness of this policy will be determined by the scale of adoption of the various technologies and fuels. Establishing baseline standards will be key to the implementation of such a policy.

Levying flat fees either at the time of registration or in the form of annual decals serves to recover revenue that is otherwise difficult to capture. However, flat fees will impose a higher effective tax on some users than on others depending on annual fuel consumption. For traditional and alternative motor fuels, a fee or decal is only needed if the intention is to provide an incentive to users of certain fuels or to generate additional revenues for infrastructure. Otherwise, there are already mechanisms for collecting fuels taxes from these vehicles, and an energycontent based tax would be a more fair and efficient way to collect revenue. The exception to this would be electric vehicles, which are not currently subject to motor fuel taxes, and other vehicles that can fuel at home. In both situations, a fee or decal can recover lost revenue, but may do so in a way that penalizes certain users if not instituted with some consideration of the array of technology options that are available.

The two approaches covered in this paper do have merit and bring positive near-term changes, but they admittedly serve more as band-aids than as large-scale solutions to transportation funding challenges. Both approaches still have inherent inefficiencies that can only be addressed by a broader overhaul and/or revisioning of how drivers pay for the roads and transit systems they use. However, in the context of alternative fuel use, these policies could serve as useful platforms to align conflicting policy priorities. 
Transportation funding is likely to be a core issue at both the state and federal levels in the years to come. There will be valuable data and insight gained from experiences with new policies and pilot programs, as a number of states are addressing these issues through creative policy solutions. The variety of approaches being pursued suggest that there is no simple or singular fix for the taxation of alternative fuels and advanced vehicle technologies. Issues of fairness, equity, and enforcement continue as challenges and identifying appropriate mechanisms for including them in a broader transportation infrastructure solution is a work in progress.

While this paper is scoped to be a primer on motor fuel excise taxes in the context of efficient and alternative fuel vehicles, there are a number of additional areas of research that can be pursued to advance the dialogue:

- Centralized information on alternative motor fuel tax rates: Specific to the current growth of alternative fuels in the market, there is a patchwork of standards, fees, and rates for various fuels in states across the country. In the absence of a unified policy or framework, having a central repository of this information would be a valuable asset to policymakers, revenue collectors, regulators, businesses, and consumers. Having easy access to this data would not only aid these entities, but also raise the public's understanding of fuel taxes and possibly increase the political feasibility of tax alterations. To some extent, this data is available in the Alternative Fuels Data Center's laws and incentives database; however, direct rates are not always provided. Organizations such as the American Petroleum Institute and IFTA also track this information to some extent, but their methodologies are geared toward a more limited scope.

- More accurate vehicle registration data: An accurate picture of the actual penetration and impact of alternative fuel vehicles and infrastructure funding is reliant on accurate data of the makeup of the current vehicle fleet. Currently, vehicle registration records are inconsistent in how alternative fuel vehicles are reported, particularly for vehicles that have been converted to run on alternative fuels using aftermarket components. This type of conversion is particularly common for natural gas and liquefied propane gas vehicles.

- A closer examination of the relationship between energy content and vehicle impact on infrastructure: This paper assumes that energy content is more indicative of impact on infrastructure than a given volume of gasoline or diesel under the assumption that the quantity of energy provided to a vehicle powertrain is more closely tied to wear and tear on roads. This assumption, however, is not validated with specific data in a way that is sufficiently rigorous to make a broad case for the correlation. The larger implication may be that there is perhaps even a better metric to use, examples that some have suggested include VMT and/or vehicle weight, with which to relate infrastructure funding and/or a use tax to.

- Enforcement of use taxes on home charging and refueling: The emergence of vehicles capable of fueling from home or in other non-traditional locations such as at shopping malls and workplaces will require a more sophisticated solution than a flat fee. Current fee or decal programs are largely effective as an incentive, but they would not be an appropriate mechanism for collecting transportation revenues on a large scale for reasons identified in this paper. Outlining the costs, benefits, and trade-offs associated with various mechanisms for revenue collection and enforcement for these vehicles will help to inform discussions 
about how to recover lost revenue in a way that does not serve as a disincentive to a specific technology.

- Removing the energy-content penalty for ethanol: Another area that deserves further attention is the energy-based taxation of ethanol. There are relatively straightforward approaches for addressing the disparity in energy content among other fuels such as $\mathrm{CNG}$, LPG, and LNG. However, taxation of ethanol is quite complicated because it is deeply embedded in the existing gasoline supply chain. Determining how to effectively address this on a large scale would remove the current penalty in place for fuels with high ethanol content.

- Energy implications of alternatives to motor fuel taxes: More work remains in determining the potential fiscal, energy, and environmental impacts of alternative taxation and revenue schemes such as VMT pricing, sales taxes, and carbon taxes. Such schemes would represent a substantial change in course for transportation infrastructure revenue, and their implications for energy use are not entirely clear. Additional opportunities, such as VMT pricing, large-scale congestion pricing, and coordinated implementation of multimodal transportation systems, are all being discussed as options. State and local governments have begun to explore or are implementing some of these alternatives. It is important that we understand the energy implications of these options to avoid repeating the current situation that places transportation funding and transportation efficiency at odds with each other. 


\section{References}

American Petroleum Institute (API). 2015a. "Gasoline Tax - July 2015.” Accessed July 12. http://www.api.org/oil-and-natural-gas-overview/industry-economics/fuel-taxes.

—. 2015b. "Diesel Tax - July 2015."Accessed July 12. http://www.api.org/oil-and-naturalgas-overview/industry-economics/fuel-taxes.

American Public Transportation Association (APTA). 2012 Public Transportation Fact Book, 63rd edition. Washington, DC: American Public Transportation Association, September 2012.

American Society of Civil Engineers (ASCE). 2013. "Report Card for America's Infrastructure." Accessed July 14, 2015. http://www.infrastructurereportcard.org.

American Trucking Associations, Inc. (ATA) v. Scheiner. 1986. 381 U.S. 532. Supreme Court of the United States. The Oyez Project at IIT Chicago-Kent College of Law. Accessed December 14, 2013. http://www.oyez.org/cases/1980-1989/1986/1986 $86 \quad 357$.

British Columbia. 2013. "Motor Fuel Tax and Carbon Tax." Accessed November 11. http://www2.gov.bc.ca/gov/content/taxes/sales-taxes/motor-fuel-carbon-tax.

California Air Resources Board (CARB). Final Regulation Order: §1962.2 Zero Emission Vehicle Standards for 2018 and subsequent Model Year Passenger Cars, Light-Duty Trucks, and Medium-Duty Vehicles, 2012.

Carolan, Michael S. "A sociological look at biofuels: Ethanol in the early decades of the twentieth century and lessons for today." Rural Sociology 74, no. 1 (2009): 86-112.

Cawley, Kim P. "Status of the Highway Trust Fund." CBO Subcommittee on Highways and Transit, Committee on Transportation and Infrastructure, U.S. House of Representatives, 2013.

Chae, H. J. et al. " $3.3 \mathrm{~kW}$ on board charger for electric vehicle." Power Electronics and ECCE Asia (ICPE \& ECCE), 2011 IEEE 8th International Conference. IEEE, 2011.

Davis, S.C., S.W. Diegel, and R.G. Boundy. 2013. Transportation Energy Data Book: Edition 32, ORNL-6989. Oak Ridge National Laboratory, Oak Ridge, TN

(US). http://cta.ornl.gov/data/index.shtml.

- 2014. Transportation Energy Data Book: Edition 33, ORNL-6990. Oak Ridge National Laboratory, Oak Ridge, TN (US). http://cta.ornl.gov/data/index.shtml.

Dinan, Terry, and David Austin. "How Would Proposed Fuel Economy Standards Affect the Highway Trust Fund?” Washington, DC: U.S. Congressional Budget Office, 2012.

Drowne, Kathleen Morgan, and Patrick Huber. The 1920s. American Popular Culture Through History Series. Santa Barbara, CA (US): Greenwood Publishing Group, 2004. 
Federal Highway Administration (FHWA). 2013a. "Annual Vehicle Distance Traveled in Miles and Related Data." Highway Statistics Series. Accessed December

15. http://www.fhwa.dot.gov/policyinformation/statistics.cfm.

_. 2013b. "Traffic Volume Trends." Office of Highway Policy Information (OHPI) Travel Monitoring. Accessed December 15, 2013. http://www.fhwa.dot.gov/policyinformation/travel_monitoring/tvt.cfm.

—. 2014a. "Funding For Highways And Disposition Of Highway-User Revenues, All Units Of Government, 2012." Highway Statistics Series. Accessed July 22, 2015. http://www.fhwa.dot.gov/policyinformation/statistics/2012/hf10.cfm

_. 2014b. "State Funding for Highways - Summary, 2012." Highway Statistics Series. Accessed July 22, 2015. http://www.fhwa.dot.gov/policyinformation/statistics/2012/.

Gautam, Deepak et al. "An automotive on-board $3.3 \mathrm{~kW}$ battery charger for PHEV application.” Vehicle Power and Propulsion Conference (VPPC), 2011 IEEE. IEEE, 2011.

Greene, D. L., J. Kahn, and R. Gibson. "Fuel economy rebound effect for US household vehicles." The Energy Journal 20, no. 3 (1999): 1-31.

Inside EVs. 2015. "Monthly Plug-In Sales Scorecard.” Accessed July 14, 2015. http://insideevs.com/monthly-plug-in-sales-scorecard/.

Institute on Taxation and Economic Policy (ITEP). "A Federal Gas Tax for the Future." Washington, DC: Institute on Taxation and Economic Policy, September 2013.

Joint Committee on Taxation Staff. General Explanation of the Revenue Provisions of the Deficit Reduction Act of 1984, 98 Cong., JCS-41-84, 1984.

Lefebvre, Ben, and Jeff Bennett. "Natural-Gas Cars to Get Home Fueling." The Wall Street Journal, November 13, 2012.

Lowry, Sean. "The Federal Excise Tax on Motor Fuels and the Highway Trust Fund: Current Law and Legislative History." Congressional Research Service. February 23, 2015.

Madowitz, Michael, and Kevin Novan. "Why sales taxes and gasoline don't mix." Washington Post, February 23, 2013.

Miller, M., A. Holmes, B. Conlon, and P. Savagian. "The GM 'Voltec' 4ET50 Multi-Mode Electric Transaxle." SAE Int. J. Engines 4, no.1 (2011):1102-1114. doi:10.4271/2011-01-0887.

National Highway and Transportation Safety Administration (NHTSA). 2012. "NHTSA and EPA Set Standards to Improve Fuel Economy and Reduce Greenhouse Gases for Passenger Cars and Light Trucks for Model Years 2017 and Beyond.” Accessed: July 22,

2015. http://www.nhtsa.gov/staticfiles/rulemaking/pdf/cafe/CAFE_2017-25_Fact_Sheet.pdf. 
National Institute of Standards and Technology. "Specifications, Tolerances, and Other Technical Requirements for Weighing and Measuring Devices.” 2012.

O’Dell, John. "Will California's Zero-Emissions Mandate Alter the Car Landscape?” Edmunds, June 24, 2012. Accessed January 30, 2014. http:/www.edmunds.com/fueleconomy/willcalifornias-zero-emissions-mandate-alter-the-car-landscape.html.

Oregon Department of Transportation. "Road Usage Charge Program (RUCP) Fact Sheet." Oregon Department of Transportation, August 2013. Accessed January, 30

2014. http://library.state.or.us/repository/2013/201309171311302/index.pdf.

Polk, R.L. POLK_VIO_DETAIL_2014. National Renewable Energy Laboratory, July 2015.

Smart, John, and Stephen Schey. "Battery Electric Vehicle and Charging Behavior Observed Early in the EV Project.” SAE International, April 16, 2012.

Society of Automotive Engineers (SAE). "Utility Factor Definitions for Plug-In Hybrid Electric Vehicles Using 2001 U.S. DOT National Household Travel Survey Data.” J2841. Hybrid EV Committee, 2010.

University of Michigan (UMTRI). "Monthly monitoring of vehicle fuel economy and emissions". August 2015. Accessed August 12,

2015. http://www.umich.edu/ umtriswt/EDI sales-weighted-mpg.html.

U.S. Department of Energy (DOE). 2013."Vehicle Fuel Efficiency (CAFE) Requirements by Year. Accessed July 22, 2015. http://www.afdc.energy.gov/data/10562.

-. 2014."E85 Specification.” Accessed January

30. http://www.afdc.energy.gov/fuels/ethanol e85 specs.html.

- 2015.“AFV and HEV Model Offerings, By Manufacturer.” Revised June 2015.

Accessed July 14. http://www.afdc.energy.gov/data/10304.

U.S. Department of Treasury, Internal Revenue Service (US IRS). 2013. "Publication 510:

Excise Taxes Including Fuel Tax Credits and Refunds." Revised July 2013. Accessed November 10, 2013. http://www.irs.gov/uac/Publication-510,-Excise-Taxes-\%28Including-Fuel-TaxCredits-and-Refunds\%29.

- 2015. "Instructions for Form 720: Quarterly Federal Excise Tax Return." Revised April 2015. Accessed June 25, 2015. http://www.irs.gov/pub/irs-pdf/i720.pdf.

U.S. Energy Information Administration (EIA). 2015a. "Draft Annual Energy Outlook 2015." Accessed July 22, 2015. http://www.eia.gov/beta/aeo/\#/?id=45-AEO2015\&cases=ref2015.

_. 2015b. "U.S. Prime Supplier Sales Volumes of Petroleum Products.” Accessed July 22, 2015. http://www.eia.gov/dnav/pet/pet_cons_prim_dcu_nus_m.htm. 
Wakefield, Ernest. History of the Electric Automobile, Hybrid Electric Vehicles. Warrendale, PA (US): Society of Automotive Engineers, 1994.

Weingroff, Richard F. "Federal-Aid Highway Act of 1956: Creating the Interstate System." Public Roads 60, no. 1 (1996).

Workman, Simon, and Jaime Rall. "Taxation of Alternative Fuels." National Conference of State Legislatures, August 2012. Accessed November 11, 2013. http://www.ncsl.org/research/transportation/taxation-of-alternative-fuels.aspx. 